\title{
AIDS and Behavior \\ HCV-Related Mortality Among HIV/HCV Co-infected Patients: The Importance of Behaviors in the HCV Cure Era (ANRS CO13 HEPAVIH Cohort) --Manuscript Draft--
}

\begin{tabular}{|c|c|c|}
\hline Manuscript Number: & \multicolumn{2}{|l|}{ AIBE-D-18-01101R2 } \\
\hline Full Title: & \multicolumn{2}{|c|}{$\begin{array}{l}\text { HCV-Related Mortality Among HIV/HCV Co-infected Patients: The Importance of } \\
\text { Behaviors in the HCV Cure Era (ANRS CO13 HEPAVIH Cohort) }\end{array}$} \\
\hline Article Type: & \multicolumn{2}{|l|}{ Original Research } \\
\hline Keywords: & \multicolumn{2}{|c|}{ Behavior; substance use; hepatitis C; HIV; mortality } \\
\hline Corresponding Author: & \multicolumn{2}{|l|}{$\begin{array}{l}\text { Maria Patrizia Carrieri, PhD } \\
\text { SESSTIM UMR } 1252 \\
\text { Marseille, FRANCE }\end{array}$} \\
\hline \multicolumn{3}{|l|}{$\begin{array}{l}\text { Corresponding Author Secondary } \\
\text { Information: }\end{array}$} \\
\hline Corresponding Author's Institution: & \multicolumn{2}{|l|}{ SESSTIM UMR 1252} \\
\hline \multicolumn{3}{|l|}{$\begin{array}{l}\text { Corresponding Author's Secondary } \\
\text { Institution: }\end{array}$} \\
\hline First Author: & \multicolumn{2}{|c|}{ Melina Erica Santos, MD, MPH, PhD candidate } \\
\hline \multicolumn{3}{|l|}{ First Author Secondary Information: } \\
\hline \multirow[t]{15}{*}{ Order of Authors: } & \multicolumn{2}{|c|}{ Melina Erica Santos, MD, MPH, PhD candidate } \\
\hline & \multicolumn{2}{|l|}{ Camelia Protopopescu, PhD } \\
\hline & \multicolumn{2}{|l|}{ Philippe Sogni, MD, PhD } \\
\hline & \multicolumn{2}{|l|}{ Issifou Yaya, PhD } \\
\hline & \multicolumn{2}{|l|}{ Lionel Piroth, MD, PhD } \\
\hline & \multicolumn{2}{|l|}{ François Bailly, MD } \\
\hline & \multicolumn{2}{|l|}{ Fabienne Marcellin, PhD } \\
\hline & \multicolumn{2}{|l|}{ Laure Esterle, PhD } \\
\hline & \multicolumn{2}{|l|}{ Linda Wittkop, MD, PhD } \\
\hline & \multicolumn{2}{|l|}{ Eric Rosenthal, MD, PhD } \\
\hline & \multicolumn{2}{|l|}{ Philippe Morlat, MD } \\
\hline & \multicolumn{2}{|l|}{ Perrine Roux, PhD } \\
\hline & \multicolumn{2}{|l|}{ Wildo Navegantes de Araújo, PhD } \\
\hline & \multicolumn{2}{|l|}{ Dominique Salmon-Ceron, MD, PhD } \\
\hline & \multicolumn{2}{|l|}{ Maria Patrizia Carrieri. PhD } \\
\hline \multicolumn{3}{|c|}{ Order of Authors Secondary Information: } \\
\hline Funding Information: & $\begin{array}{l}\text { Agence Nationale de Recherches sur le } \\
\text { Sida et les Hépatites Virales (FR) }\end{array}$ & Not applicable \\
\hline Abstract: & \multicolumn{2}{|c|}{$\begin{array}{l}\text { Mortality among individuals co-infected with HIV and hepatitis } \mathrm{C} \text { virus }(\mathrm{HCV} \text { ) is } \\
\text { relatively high. We evaluated the association between psychoactive substance use and } \\
\text { both HCV and non-HCV mortality in HIV/HCV co-infected patients in France, using } \\
\text { Fine \& Gray's competing-risk model adjusted for socio-demographic, clinical predictors } \\
\text { and confounding factors, while accounting for competing causes of death. Over a 5- } \\
\text { year median follow-up period, } 77 \text { deaths occurred among } 1,028 \text { patients. Regular/daily } \\
\text { cannabis use, elevated coffee intake, and not currently smoking were independentiy } \\
\text { associated with reduced HCV-mortality (adjusted sub-hazard ratio [ } 95 \% \mathrm{Cl} \text { : } 0 \cdot 28[0 \cdot 10 \text { - }\end{array}$} \\
\hline
\end{tabular}


$0 \cdot 83$ ], $0 \cdot 38[0 \cdot 15-0 \cdot 95]$, and $0 \cdot 28[0 \cdot 10-0 \cdot 79]$, respectively). Obesity and severe thinness

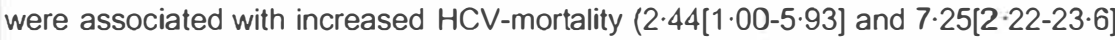
versus normal weight, respectively). Regular binge drinking was associated with increased non-HCV-mortality $(2 \cdot 19[1 \cdot 10-4 \cdot 37])$. Further research is needed to understand the causal mechanisms involved. People living with HIVIHCV co-infection should be referred for tobacco, alcohol and weight control interventions and potential benefits of cannabis-based therapies investigated.

Response to Reviewers:

Thank you very much for your comments and important contributions to our work. We hope that after these minor revisions, our manuscript will be suitable for publication in AIDS and Behavior. 


\section{Title}

HCV-Related Mortality Among HIV/HCV Co-infected Patients: The Importance of Behaviors in the HCV Cure Era (ANRS CO13 HEPAVIH Cohort)

\section{Authors' names}

Melina Erica SANTOS ${ }^{1,2,3}$, Camelia PROTOPOPESCU ${ }^{2,3}$, Philippe SOGNI ${ }^{4,5,6}$, Issifou YAYA ${ }^{2,3}$, Lionel PIROTH ${ }^{7,8}$, François BAILLY ${ }^{9,10}$, Fabienne MARCELLIN ${ }^{2,3}$, Laure ESTERLE $^{11}$, Linda WITTKOP $^{11,12}$, Eric ROSENTHAL ${ }^{13,14}$, Philippe MORLAT $^{15}$, Perrine ROUX ${ }^{2,3}$, Wildo Navegantes de ARAUJO $^{16}$, Dominique SALMON-CERON ${ }^{6,17}$, Maria Patrizia CARRIERI ${ }^{2,3} \&$ the ANRS CO13 HEPAVIH Study Group

\section{Authors' affiliations}

${ }^{1}$ Faculdade de Ciências da Saúde, Universidade de Brasília, Brasília, Brasil.

2.INSERM, IRD, SESSTIM, Sciences Economiques \& Sociales de la Santé \& Traitement de l’Information Médicale, Aix Marseille Université, Marseille, France.

${ }^{3}$ Observatoire régional de la santé Provence-Alpes-Côte d'Azur, ORS PACA, Marseille, France.

${ }^{4}$ Service d'Hépatologie, Hôpital Cochin, AP-HP, Paris, France.

${ }^{5}$ INSERM U-1223, Institut Pasteur, Paris, France.

${ }^{6}$ Université Paris Descartes - Sorbonne Paris Cité, Paris, France.

${ }^{7}$ Département d'Infectiologie, CHU de Dijon, Dijon, France.

${ }^{8}$ INSERM - CIC 1342, Université de Bourgogne, Dijon, France.

${ }^{9}$ Service d'Hépatologie et Gastroentérologie, Hôpital de la Croix-Rousse, Lyon, France.

${ }^{10}$ INSERM U1052, Centre de Recherche en Cancérologie de Lyon, Lyon, France. 
${ }^{11}$ Bordeaux Population Health Research Center, INSERM U1219, CIC-EC 1401, Univ. Bordeaux - ISPED, Bordeaux, France.

${ }^{12 .}$ Service d'information médicale, CHU de Bordeaux, Bordeaux, France.

${ }^{13 .}$ Service de Médecine Interne, Hôpital l'Archet, CHU de Nice, Nice, France.

14.LAMHESS, Université de Nice-Sophia Antipolis, Nice, France.

${ }^{15}$ Service de Médecine Interne et Maladies Infectieuses, CHU de Bordeaux, Bordeaux, France.

${ }^{16}$ Faculdade UnB Ceilândia, Universidade de Brasília, Brasília, Brasil.

${ }^{17}$ Service de Maladies Infectieuses et Tropicales, Hôpital Cochin, AP-HP, Paris, France.

\section{Corresponding author}

Name: Maria Patrizia Carrieri

Mailing address: INSERM UMR1252 SESSTIM. IHU Méditerranée Infection. 19-21 Boulevard Jean Moulin, 13005 Marseille, France.

Email address: pmcarrieri@aol.com

Telephone number: + 330413732281

\section{Running head}

Behavioral correlates of HCV mortality 


\section{Authors' contributions}

Study concept and design: MPC, CP, DSC. Acquisition of data: LW, LE, LP, FB, ER, PM, PS, DSC. Analysis and interpretation of data: CP, MES, MPC. Drafting of the manuscript: MES, MPC, CP, FM. Critical revision of the manuscript for important intellectual content: MPC, FM, DSC, WNA, LW, LE, ER, PS, PM, IY, PR, LP, FB. Statistical analysis: CP. Obtained funding: LW, MPC. Administrative, technical, or material support: FM, LE. Study supervision: MPC. All authors approved the final revised version of the manuscript. 


\section{Acknowledgements}

Funding: ANRS (France Recherche Nord \& sud Sida-hiv Hépatites). English review: Jude Sweeney. Patients in the HEPAVIH Cohort. Scientific Committee of the ANRS CO13 HEPAVIH Study Group: D. Salmon (co-Principal investigator), L. Wittkop (co-Principal Investigator), P. Sogni (co-Principal Investigator), L. Esterle (project manager), P. Trimoulet, J. Izopet, L. Serfaty, V. Paradis, B. Spire, P. Carrieri, M.A. Valantin, G. Pialoux, J. Chas, I. Poizot-Martin, K. Barange, A. Naqvi, E. Rosenthal, A. Bicart-See, O. Bouchaud, A. Gervais, C. Lascoux-Combe, C. Goujard, K. Lacombe, C. Duvivier, D. Vittecoq, D. Neau, P. Morlat, F. Bani-Sadr, L. Meyer, F. Boufassa, S. Dominguez, B. Autran, A.M. Roque, C. Solas, H. Fontaine, D. Costagliola, L. Piroth, A. Simon, D. Zucman, F. Boué, P. Miailhes, E. Billaud, H. Aumaître, D. Rey, G. Peytavin, V. Petrov-Sanchez, A. Pailhé. Clinical Centres (ward / participating physicians): APHP Cochin, Paris (Médecine Interne et Maladies Infectieuses : D. Salmon, R. Usubillaga ; Hépato-gastro-entérologie : P. Sogni ; Anatomo-pathologie : B. Terris ; Virologie :P. Tremeaux) ; APHP Pitié-Salpétrière, Paris (Maladies Infectieuses et Tropicales : C. Katlama, M.A. Valantin, H. Stitou ; Hépato-gastroentérologie : Y. Benhamou ; Anatomo-pathologie : F. Charlotte ; Virologie : S. Fourati) ; APHP Pitié-Salpétrière, Paris (Médecine Interne : A. Simon, P. Cacoub, S. Nafissa) ; APHM SainteMarguerite, Marseille (Service d'Immuno-Hématologie Clinique : I. Poizot-Martin, O. Zaegel, H. Laroche ; Virologie : C. Tamalet); APHP Tenon, Paris (Maladies Infectieuses et Tropicales : G. Pialoux, J. Chas,; Anatomo-pathologie : P. Callard, F. Bendjaballah ; Virologie : C. Le Pendeven) ; CHU Purpan, Toulouse (Maladies Infectieuses et Tropicales : B. Marchou ; Hépato-gastroentérologie : L. Alric, K. Barange, S. Metivier ; Anatomo-pathologie : J. Selves ; Virologie : F. Larroquette) ; CHU Archet, Nice (Médecine Interne : E. Rosenthal ; Infectiologie : A. Naqvi, V. Rio ; Anatomo-pathologie : J. Haudebourg, M.C. Saint-Paul ; Virologie : C. Partouche) ; APHP Avicenne, Bobigny (Médecine Interne - Unité VIH : O. Bouchaud; Anatomo-pathologie : M. Ziol 
; Virologie : Y. Baazia) ; Hôpital Joseph Ducuing, Toulouse (Médecine Interne : M. Uzan, A. Bicart-See, D. Garipuy, M.J. Ferro-Collados ; Anatomo-pathologie : J. Selves ; Virologie : F. Nicot) ; APHP Bichat - Claude-Bernard, Paris (Maladies Infectieuses :, A. Gervais, Y. Yazdanpanah; Anatomo-pathologie : H. Adle-Biassette ; Virologie : G. Alexandre) ; APHP SaintLouis, Paris (Maladies infectieuses : C. Lascoux-Combe, J.M. Molina,; Anatomo-pathologie : P. Bertheau,; Virologie :M.L. Chaix, C. Delaugerre, S. Maylin) ; APHP Saint-Antoine (Maladies Infectieuses et Tropicales :, K. Lacombe, J. Bottero; J. Krause P.M. Girard, Anatomo-pathologie : D. Wendum, P. Cervera, J. Adam ; Virologie : C. Viala) ; APHP Bicêtre, Paris (Médecine Interne : C. Goujard, Y. Quertainmont, E. Teicher; Virologie : C. Pallier ; Maladies Infectieuses : D. Vittecoq) ; APHP Necker, Paris (Maladies Infectieuses et Tropicales : O. Lortholary, C. Duvivier, C. Rouzaud, J. Lourenco, F. Touam, C. Louisin : Virologie : V. Avettand-Fenoel, A. Mélard) ; CHU Pellegrin, Bordeaux (Maladies Infectieuses et Tropicales : D. Neau, A. Ochoa, E. Blanchard, S. Castet-Lafarie, C. Cazanave, D. Malvy, M. Dupon, H. Dutronc, F. Dauchy, L. Lacaze-Buzy ; Anatomo-pathologie : P. Bioulac-Sage ; Virologie : P. Trimoulet, S. Reigadas) ; Hôpital SaintAndré, Bordeaux (Médecine Interne et Maladies Infectieuses : Médecine Interne et Maladies Infectieuses : P. Morlat, D. Lacoste, F. Bonnet, N. Bernard, M. Hessamfar, J, F. Paccalin, C. Martell, M. C. Pertusa, M. Vandenhende, P. Merciéer, D. Malvy, T. Pistone, M.C. Receveur, M. Méchain, P. Duffau, C Rivoisy, I. Faure, S. Caldato ; Anatomo-pathologie : P. Bioulac-Sage ; Virologie : P. Trimoulet, S. Reigadas) ; Hôpital du Haut-Levêque, Bordeaux (Médecine Interne : J.L. Pellegrin, J.F. Viallard, E. Lazzaro, C. Greib ; Anatomo-pathologie : P. Bioulac-Sage ; Virologie : P. Trimoulet, S. Reigadas) ; Hôpital FOCH, Suresnes (Médecine Interne : D. Zucman, C. Majerholc ; Virologie : E. Farfour) ; APHP Antoine Béclère, Clamart (Médecine Interne : F. Boué, J. Polo Devoto, I. Kansau, V. Chambrin, C. Pignon, L. Berroukeche, R. Fior, V. Martinez; Virologie : C. Deback) ; CHU Henri Mondor, Créteil (Immunologie Clinique : Y. Lévy, S. 
Dominguez, J.D. Lelièvre, A.S. Lascaux, G. Melica) ; CHU Hôtel Dieu, Nantes (Maladies Infectieuses et Tropicales : E. Billaud, F. Raffi, C. Allavena, V. Reliquet, D. Boutoille, C. Biron; Virologie : A. Rodallec, L. Le Guen); Hôpital de la Croix Rousse, Lyon (Maladies Infectieuses et Tropicales : P. Miailhes, D. Peyramond, C. Chidiac, F. Ader, F. Biron, A. Boibieux, L. Cotte, T. Ferry, T. Perpoint, J. Koffi, F. Zoulim, F. Bailly, P. Lack, M. Maynard, S. Radenne, M. Amiri ; Virologie : C. Scholtes, T.T. Le-Thi) ; CHU Dijon, Dijon (Département d'infectiologie :, L. Piroth, P. Chavanet M. Duong Van Huyen, M. Buisson, A. Waldner-Combernoux, S. Mahy, R. Binois, A.L. Simonet-Lann, D. Croisier-Bertin) ; CH Perpignan, Perpignan (Maladies infectieuses et tropicales : H. Aumaître) ; CHU Robert Debré, Reims (Médecine interne, maladies infectieuses et immunologie clinique : F. Bani-Sadr, D. Lambert, Y Nguyen, J.L. Berger) ; CHRU Strasbourg (Le Trait d'Union : D Rey, M Partisani, ML Batard, C Cheneau, M Priester, C Bernard-Henry, E de Mautort, Virologie : P Gantner et S Fafi-Kremer), APHP Bichat-Claude Bernard (Pharmacologie : G. Peytavin). Data collection: F. Roustant, I. Kmiec, L. Traore, S. Lepuil, S. Parlier, V. SicartPayssan, E. Bedel, F. Touam, C. Louisin, M. Mole, C. Bolliot, M. Mebarki, A. Adda-Lievin, F.Z. Makhoukhi, O. Braik, R. Bayoud, M.P. Pietri, V. Le Baut, D. Bornarel, C. Chesnel, D. Beniken, M. Pauchard, S. Akel, S. Caldato, C. Lions, L. Chalal, Z. Julia, H. Hue, A. Soria, M. Cavellec, S. Breau, A. Joulie, P. Fisher, C. Ondo Eyene, S. Ogoudjobi, C. Brochier, V. Thoirain-Galvan. Management, statistical analyses: E. Boerg, P. Carrieri, V. Conte, L. Dequae-Merchadou, M. Desvallees, N. Douiri, L. Esterle, C. Gilbert, S. Gillet, R. Knight, F. Marcellin, L. Michel, M. Mora, C. Protopopescu, P. Roux, B. Spire, S. Tezkratt, I. Yaya, T. Barré, T. Rojas, V. Villes, M. Baudoin, M. Santos. 


\begin{abstract}
Word count: 149)
Mortality among individuals co-infected with HIV and hepatitis C virus (HCV) is relatively high. We evaluated the association between psychoactive substance use and both HCV and non-HCV mortality in HIV/HCV co-infected patients in France, using Fine \& Gray's competing-risk model adjusted for socio-demographic, clinical predictors and confounding factors, while accounting for competing causes of death. Over a 5-year median follow-up period, 77 deaths occurred among 1,028 patients. Regular/daily cannabis use, elevated coffee intake, and not currently smoking were independently associated with reduced $\mathrm{HCV}$-mortality (adjusted sub-hazard ratio $[95 \% \mathrm{CI}]$ : $0 \cdot 28[0 \cdot 10-0 \cdot 83], 0 \cdot 38[0 \cdot 15-0 \cdot 95]$, and $0 \cdot 28[0 \cdot 10-0 \cdot 79]$, respectively). Obesity and severe thinness were associated with increased HCV-mortality $(2 \cdot 44[1 \cdot 00-5 \cdot 93]$ and $7 \cdot 25[2 \cdot 22-23 \cdot 6]$ versus normal weight, respectively). Regular binge drinking was associated with increased non-HCVmortality $(2 \cdot 19[1 \cdot 10-4 \cdot 37])$. Further research is needed to understand the causal mechanisms involved. People living with HIV/HCV co-infection should be referred for tobacco, alcohol and weight control interventions and potential benefits of cannabis-based therapies investigated.
\end{abstract}

\title{
Key words
}

Behavior; substance use; hepatitis C; HIV; mortality 


\section{Introduction}

Individuals co-infected with human immunodeficiency virus (HIV) and hepatitis $\mathrm{C}$ virus (HCV) experience accelerated progression of chronic liver disease[1] and higher mortality[2]. HIV infection has been associated with persistent $\mathrm{HCV}$ viremia and reduced response to Peg-interferonbased HCV treatment. Furthermore, it has been hypothesized that HCV infection could interfere with HIV-specific T cells, and thus accelerate HIV progression[3].

Since the introduction of antiretroviral therapy (ART) for HIV, HCV-related complications mainly end-stage liver disease and hepatocellular carcinoma (HCC) - have become the leading causes of death in HIV/HCV co-infected individuals. Controlling HIV viremia has led to reduced HIV-related mortality, fewer interactions between HCV and HIV, and the emergence of non-HIVrelated causes of death[2]. Moreover, the arrival of direct-acting antiviral agents for HCV has resulted in a substantial decrease of many complications associated with liver disease and extrahepatic dysfunction, improving clinical outcomes and patient survival[4]. However, morbidity and mortality remain high due to complications associated with both HCV and HIV, in particular metabolic disorders (e.g., insulin resistance and dyslipidaemia) which are also associated with the occurrence of cardiovascular events[5-7].

In France, the prevalence of HIV/HCV co-infection in people living with HIV was estimated at between $16 \%$ and $18 \%$ in 2011 [8]. Since 2010, the proportion of HCV-related causes of death has increased among co-infected individuals[9-11]. Although HIV/HCV co-infection had been historically linked to intravenous drug use in France[12,13], its prevalence is expected to decrease in this at-risk population[14]. This highlights the importance of investigating other behavioral factors associated with mortality.

Given that almost all co-infected patients can now be cured of HCV infection and that HIV viremia can be controlled, HIV- and HCV-related deaths may compete in different ways in this population. 
We hypothesize that specific behaviors can be more predictive of HCV-related mortality today than they were before. Accordingly, using data from the French ANRS CO13 HEPAVIH cohort of $\mathrm{HIV} / \mathrm{HCV}$ patients, we made a detailed exploration of the following behaviors, all known to be associated with specific comorbidities in HIV/HCV patients: smoking, alcohol consumption, coffee consumption and cannabis use.

We investigated smoking for two main reasons. First, it has already been associated with overall mortality in the HEPAVIH cohort[15] and accounted for a considerable proportion of the deaths in a HIV/HCV cohort study in Canada[16]. Second, the impact of smoking on liver disease progression is debatable, as it was not found to be a risk factor for accelerated liver disease in the Canadian cohort[17], despite being identified as a risk factor for liver cancer[18]. Alcohol consumption is universally recognized as a risk factor for liver disease[19] and its progression[20], although it is unknown whether it is a risk factor of HCV-related mortality in HIV/HCV co-infected patients[21]. Coffee is widely known to have hepatoprotective properties[22] and, in the HEPAVIH population, consumption of three or more cups/day was a major protective factor of overall mortality[15]. Cannabis use was previously associated with reduced risk of insulin resistance[23] and liver steatosis[24] in HIV/HCV co-infected patients, and also in the general population[25], but no significant effect on liver fibrosis has been highlighted[26,27]. We hypothesized that the benefits of cannabis can also be observed for HCV-related mortality.

The aim of the present study was to assess the association between the four above-mentioned behaviors and HCV-related mortality, after adjustment for other behavioral and sociodemographic characteristics, while accounting for competing causes of death.

\section{Methods}

\section{Study design and setting}


ANRS CO13 HEPAVIH is a French hospital-based multicenter prospective cohort, representative of the HIV/HCV co-infected population in care nationwide. It included 1,246 patients between 2005 and 2014. Cohort details were described elsewhere[28]. All patients provided signed informed consent at enrolment. The ethics committee of the Cochin University Hospital in Paris approved the study protocol[28].

\section{Follow-up and data collection}

Clinical follow-up visits were scheduled once a year for non-cirrhotic patients, and every six months for cirrhotic patients. Physicians filled in a standardized clinical form at each visit, which collected data regarding $\mathrm{HIV}$ and $\mathrm{HCV}$ clinical and biological characteristics and disease history[28]. Patients' vital status was confirmed by participating centers and, for patients lost to follow-up 24 months after enrolment, this information was obtained from the national death registry. A medical expert committee validated the classification of causes of death based on clinical record review[15]. In addition, patients answered a self-administered questionnaire at enrolment (M0) and yearly thereafter until 60 months (M60). It collected data on sociodemographic, psychosocial and behavioral characteristics including the four behaviors under study here[28].

\section{Participants and follow-up}

Patients who had at least one completed self-administered questionnaire during follow-up and a latest news date (follow-up visit or death) subsequent to their entry date (i.e. having at least two time points with available information during the cohort follow-up) were eligible for this study. The follow-up period for each eligible patient was defined as the period between the first followup visit with completed self-administered questionnaire (hereafter "baseline visit") and the latest news date. As self-administered questionnaires were scheduled every 12 months until M60, in order to study the impact of the covariates measured at each visit on the risk of death during the 
subsequent 12 months, the latest news date was censored at 72 months after enrolment. More details about participant selection are provided elsewhere[15].

\section{Outcome}

All deaths of eligible patients during the follow-up period were included in this study. We performed two separate analyses, the first with the outcome HCV-related deaths, and the second with the outcome non-HCV-related deaths (i.e. deaths related to HIV, cancer-related deaths not connected to HIV or HCV, and deaths from other causes).

\section{Explanatory variables}

To investigate the association between behaviors and HCV- and non-HCV-related mortality, we adjusted for socioeconomic and clinical characteristics known to be associated with the outcome. Socioeconomic factors included the following: having a steady partner, being employed, having children, and housing comfort and stability. Comfortable housing was defined as reporting "quite comfortable" or "very comfortable" versus "uncomfortable" or "quite uncomfortable" housing[29]. Unstable housing was defined as living in hotels, accommodation centers, on the street, or in therapeutic apartments[15]. Clinical variables focused on HCV and HIV and included time since HIV and HCV diagnosis, CD4 count, HIV CDC clinical stage, ART, HCV genotype and cure. We considered the following HIV transmission categories: injecting drug use (IDU), men who have sex with men (MSM), heterosexual/other causes. A history of HCC and/or liver transplantation and a history of indirect clinical signs of cirrhosis (ascites, oesophageal varices with or without bleeding, or hepatic encephalopathy) were assessed at enrolment. Severe liver fibrosis was defined by an FIB-4 index $>3 \cdot 25$ (corresponding to an F3-F4 METAVIR score)[30]. Adherence to ART was assessed using a three-level adherence score (low, moderate, high) based on the AIDS Clinical Trial Group methodology[31]. Depressive symptoms were investigated using the Center for Epidemiological Studies Depression Scale (CES-D), with a score $\geq 17$ for men, and 
$\geq 23$ for women indicating depressive symptoms[32]. Body mass index (BMI) status was defined by five categories: severely thin $(\mathrm{BMI}<16)$, underweight (BMI: 16·0-18·49), normal weight (BMI: 18·49-24·99), overweight (BMI: 25·0-29·9), and obese (BMI $\geq 30)$.

Drug use was investigated with the question: "During the last four weeks, have you used the following drug?" which was followed by a list of drugs. Possible answers to each item were "never", "sometimes", "regularly", and "daily". For cannabis/marijuana use we chose a binary response variable: "regularly/daily" versus "never/sometimes". Patients who answered "never", but who reported to their physician that they smoked at least one joint per day were reclassified as regular/daily cannabis users. We also tested two variables related to other drug use, namely nonprescribed opioid use (heroin, buprenorphine) and stimulant drug use (cocaine, crack, ecstasy, amphetamine, LSD and other hallucinogenic drugs).

Smoking status was defined as current smoking versus never or past smoking. We used the following categories for coffee intake: low ( $\leq 1$ cup/day), moderate ( 2 cups/day), and elevated ( $\geq 3$ cups/day)[15]. Alcohol consumption was assessed using the Alcohol Use Disorders Identification Test-Consumption questionnaire (AUDIT-C)[33]. One alcohol unit (AU) was defined as a standard drink containing 11-14g of alcohol. We used the following categories of alcohol consumption: no consumption, low ( $\leq 1$ AU/day), moderate (1-3 AU/day for women; 1-4 AU/day for men), and elevated consumption ( $>3 \mathrm{AU} /$ day for women; $>4 \mathrm{AU} /$ day for men). Regular binge drinking was defined as drinking $\geq 5 \mathrm{AU}$ on one occasion at least once a week.

The time-fixed covariates measured at baseline were: gender, HCV genotype, HIV transmission category, history of HCC and/or liver transplantation, history of indirect clinical signs of cirrhosis, smoking status, alcohol consumption, regular binge drinking, coffee intake, cannabis use, nonprescribed opioid use, and stimulant drug use. We considered baseline measures of behavioral characteristics in order to avoid the risk of reverse causation. All other explanatory variables were 
used as time-varying covariates (measured at each visit). The time-fixed and time-varying covariates are shown in Tables 3 and 4.

\section{Statistical analyses}

$\mathrm{HCV}$-related and non-HCV-related mortality rates were computed as the number of corresponding deaths divided by the number of person-years during the study period (computed as the sum, for all patients, of the number of years between entry date and latest news date, i.e., death, latest followup visit, or censoring). The 'last observation carried forward' method was used to impute the missing values for the time-varying explanatory variables (i.e., at clinical visits without selfadministered questionnaires). We used Fine and Gray's competing-risk proportional sub-hazards model[34] with robust standard errors to estimate the effect of behavioral characteristics on HCVrelated and non-HCV-related mortality, adjusting for potential socio-demographic and clinical predictors and confounding factors.

Explanatory variables with a p-value $<0 \cdot 20$ (Wald test) in the univariable analyses were considered eligible for inclusion in the multivariable analysis. To account for potential interaction effects between tobacco and cannabis, and given that both tobacco and HCV cure are major predictors of overall mortality in this population, we included smoking status and $\mathrm{HCV}$ cure in the multivariable models, irrespective of their p-values in the univariable analyses. We also adjusted the multivariable models for gender and age, irrespective of p-values.

We used a backward selection procedure based on the Wald test to identify significant variables in the final multivariable models ( $\mathrm{p}$-value $\leq 0 \cdot 05$ ), separately for $\mathrm{HCV}$-related and non-HCV-related mortality. The presence of confounding factors was evaluated by testing each non-significant variable (the tested variable was considered a confounder and included in the final model if at least one of the coefficients for the other variables changed by more than $25 \%$ ). Interactions were assessed by creating interaction terms and adding them to the main effects model, to test for their 
significance. The proportional-sub-hazard assumption was tested graphically, using cumulative incidence functions, and by testing time interactions for each covariate. Stata/SE $14 \cdot 2$ software (StataCorp LP, College Station, USA) was used for all analyses.

\section{Results}

\section{Study participants}

Among the 1,246 patients included in the cohort between 2005 and November 2014, 1,051 had at least one completed self-administered questionnaire. Of these, 1,028 had a latest news date subsequent to their entry date, and so were eligible for analyses. With regard to study participants, $722(70 \cdot 2 \%)$ were men and the principal HIV transmission category was IDU $(63 \cdot 2 \%)$. At enrolment, $31(3.0 \%)$ had a history of HCC and/or liver transplantation, and $30(2.9 \%)$ had a history of indirect clinical signs of cirrhosis. At the last available visit, median age was 49 years [interquartile range (IQR) 46-52 years], 972 patients $(94 \cdot 5 \%)$ were receiving ART, $566(55 \cdot 1 \%)$ had CD4>500 cells $/ \mathrm{mm}^{3}, 162(15 \cdot 8 \%)$ had severe liver fibrosis (FIB-4>3 25$)$, and $247(24 \cdot 0 \%)$ were cured post-HCV-treatment. With regard to socio-behavioral characteristics measured at baseline, 738 patients $(71 \cdot 8 \%)$ were current smokers, $274(26 \cdot 6 \%)$ had elevated coffee intake, 143 $(13 \cdot 9 \%)$ were regular binge drinkers, $255(24 \cdot 8 \%)$ used cannabis regularly or daily, $37(3.6 \%)$ used non-prescribed opioids, and 87 (8.5\%) used stimulant drugs (Table 2).

Among the 1,028 study participants, accounting for 4,700 person-years, 77 deaths occurred over the median 5-year follow-up period as follows: 33 (42.9\%) were HCV-related, 8 (10.4\%) were HIV-related, $9(11 \cdot 7 \%)$ were cancer-related, and $27(35 \cdot 1 \%)$ were deaths from other causes. The distribution of causes of deaths in each category is described in Table 1. Mortality rate per 100 person-years $[95 \%$ confidence interval $(\mathrm{CI})]$ was $1 \cdot 64[1 \cdot 31-2 \cdot 05]$ for all-cause deaths, $0 \cdot 70[0 \cdot 50$ 0.99] for HCV-related deaths, and 0.94 [0.70-1.26] for non-HCV-related deaths. Among the 33 HCV-related deaths, $29(87 \cdot 9 \%)$ occurred in men, $22(66 \cdot 7 \%)$ in patients with severe fibrosis, and 
$16(48 \cdot 5 \%)$ in those with a history of HCC and/or liver transplantation. Patients who died from HIV-related causes were younger (median age: 45 years) than those who died from other causes (median age ranged from 48 years in patients who died from HCV-related causes to 50 years in patients who died from cancer) (Table 2).

\section{Univariable analyses}

Factors associated with reduced HCV-related mortality were female gender, post-treatment HCVcure, HCV genotype 2/3, employment, and elevated coffee intake (Table 3). Factors associated with increased HCV-related mortality were a history of HCC and/or liver transplantation, a history of indirect clinical signs of cirrhosis, severe fibrosis, CD4 count $\leq 200$ and $200-350$, BMI $<16$ and $\geq 30$, and unstable housing.

With respect to non-HCV-related mortality, post-treatment HCV-cure, having children, comfortable housing, having a steady partner, and being employed were all associated with reduced non-HCV-related mortality. By contrast, HIV CDC clinical stage $\mathrm{C}$, regular binge drinking and unstable housing were all associated with increased non-HCV-related mortality.

No association was found for either non-prescribed opioid use or stimulant drug use at baseline and both HCV-related and non-HCV-related mortality (Table 3).

\section{Multivariable analysis}

In the multivariable analysis (Table 4), regular or daily cannabis use was associated with decreased HCV-related mortality (adjusted sub-hazard ratio (aSHR) [95\% CI]: $0 \cdot 28[0 \cdot 10-0 \cdot 83]$ ), as well as never or past smoking and elevated coffee intake $(0 \cdot 28[0 \cdot 10-0 \cdot 79]$ and $0 \cdot 38[0 \cdot 15-0 \cdot 95]$, respectively).

In contrast, a history of HCC and/or liver transplantation was associated with increased HCVrelated mortality $(15 \cdot 1[4 \cdot 68-49 \cdot 0])$. This was also true for severe thinness and obesity $(7 \cdot 25[2 \cdot 22$ $23 \cdot 6]$ and 2·44[1·00-5·93], respectively, versus normal weight), CD4 count $\leq 200$ and 200-350 
$(5 \cdot 24[1 \cdot 99-13 \cdot 8]$ and $3 \cdot 30[1 \cdot 23-8 \cdot 84]$, respectively, versus CD4 $>500)$, and a history of indirect clinical signs of cirrhosis $(4 \cdot 46[1 \cdot 55-12 \cdot 8])$.

With regard to non-HCV-related deaths, having a steady partner and comfortable housing were independently associated with reduced non-HCV-related mortality $(0 \cdot 48[0 \cdot 26-0 \cdot 90]$ and $0 \cdot 51[0 \cdot 26-0 \cdot 99]$, respectively). Furthermore, HIV CDC clinical stage $\mathrm{C}$ and regular binge drinking were associated with increased non-HCV-related mortality $(2 \cdot 87[1 \cdot 53-5 \cdot 37]$ and $2 \cdot 19[1 \cdot 10-4 \cdot 37]$, respectively).

Interestingly, being cured after HCV treatment was not associated with either HCV-related or nonHCV-related mortality. We found no indication that the proportionality assumption was violated (Figure 1), and no significant interaction in the multivariable models.

\section{Discussion}

This study is the first to explore the role of cannabis use on HCV-related mortality using a competing-risk approach in HIV/HCV co-infected patients while adjusting for other behavioral and clinical factors. In a previous investigation on the same cohort, elevated coffee consumption ( $\geq 3$ cups/day) was associated with a $50 \%$ reduced all-cause mortality risk[15]. The present study showed - after adjustment for HCV cure and immune restoration (measured by CD4 count) - an independent association between coffee intake and decreased HCV-related mortality in co-infected patients, and revealed two other behavioral factors associated with reduced HCV-related mortality: regular/daily cannabis use and never/past tobacco smoking. These results are important as they suggest that social interventions and behavioral changes can further decrease HCV-related mortality in this population.

The main innovation of this study is the competing-risk approach used to analyze deaths related to $\mathrm{HCV}$ in the presence of competing deaths related to HIV, cancer and other causes. This is 
particularly pertinent today given that a HCV cure exists and that greater knowledge is needed about risk factor patterns of competing causes of death in $\mathrm{HIV} / \mathrm{HCV}$ co-infected individuals. Our results concerning cannabis use are consistent with previous investigations. Cannabidiol - a non-psychotropic component of cannabis - has demonstrated antioxidant and anti-inflammatory effects which reduce liver damage by attenuating hepatic ischemia-reperfusion[35]. Furthermore, two different studies highlighted that daily cannabis use was associated with lower prevalence of steatosis[24] and was not associated with fibrosis or cirrhosis progression[36,37]. Considering that insulin resistance (IR) has been associated with a higher risk of HCC in chronic HCV infection[38], we hypothesize that the inverse association between cannabis use and HCV-related mortality is the result of the lower risk of developing IR[23], and the possible association between cannabinoids (contained in cannabis) and anti-proliferative stimulation in $\mathrm{HCC}[39]$.

The independent association we found between elevated coffee intake and decreased HCV-related mortality is also consistent with previous findings, which correlated coffee consumption with a lower risk of death from all causes in people with HIV/HCV co-infection[15]. This hepatoprotective effect of elevated coffee intake is probably due to anti-inflammatory properties of certain coffee compounds, such as polyphenols[40,41]. It is also possible that coffee intake is a confounder of other clinical conditions given that elevated coffee consumption has been directly associated with reduced IR and lower levels of liver fibrosis[41], and inversely associated with abnormal liver enzymes[40].

Furthermore, the association we found between never or past smoking and reduced HCV-related mortality is in line with previous evidence that smoking is associated with excess all-cause mortality in HIV/HCV co-infected individuals[42]. The reduced risk of HCV-related deaths for non-current smokers underlines the importance of tobacco cessation in this population for improved survival. 
Previous studies already highlighted an inverse association between CD4 count and progression to advanced liver fibrosis in HIV/HCV co-infected patients[1]. In the present study, we demonstrated that lower CD4 levels were associated with increased HCV-related mortality, even after controlling for clinical signs of cirrhosis and history of HCC. HIV CDC clinical stage C was associated with increased non-HCV-related mortality. This finding is most likely due to HIV disease progression, and confirms previous findings that higher CD4 counts are associated with lower risk of clinical events and deaths[1].

Other studies have identified advanced liver fibrosis and HCC as predictors of liver-related deaths in $\mathrm{HIV} / \mathrm{HCV}$ co-infected patients[2]. Likewise, our study found an independent association between HCV-related mortality and a history of clinical signs of cirrhosis and HCC/liver transplantation, after accounting for competing causes of death. Moreover, achieving sustained virological response after HCV treatment has been associated with extended survival in patients with compensated cirrhosis[4]. However, in our study we did not find a significant association between $\mathrm{HCV}$ cure and either HCV-related or non-HCV-related mortality in multivariable analysis. The lack of long-term data after HCV treatment may explain this result. However, even though $\mathrm{HCV}$ cure has been associated with reduced HCC incidence after HCV-treatment, and with a lower relative reduction of $\mathrm{HCC}$ risk in patients with cirrhosis[43], the results in our population suggest that severe complications of liver disease are more predictive of death, and underline the importance of early HCV treatment in HIV/HCV co-infection.

Our findings regarding BMI are consistent with previous results highlighting the association between both overweightness and obesity and all-cause mortality[44]. Additionally, we found that severe thinness is associated with HCV-related mortality. We hypothesize that this can be explained by the increased risk of cardiovascular events associated with severe thinness in our population. Another study found that a BMI below 18.5 was associated with increased all-cause 
mortality in the general population[45] and may be a potential independent risk factor for cardiovascular disease[46].

Having a steady partner was associated with lower non-HCV-related mortality. This result is consistent with previous investigations showing that having no partner was associated with an increased mortality rate when compared with having a steady partner, after accounting for various aspects of social network and for socioeconomic status[47]. The association between comfortable housing and reduced non-HCV-related mortality may be explained by considering housing conditions as a determinant of health. One systematic review concluded that improving housing conditions not only promotes better health outcomes, but also enhances determinants of health, such as diet and social relationships[48].

At last, we found an association between regular binge drinking and non-HCV-related mortality. This is consistent with studies showing that binge drinking is independently associated with increased all-cause mortality[49]. Given that alcohol misuse is often under-reported among $\mathrm{HIV} / \mathrm{HCV}$ co-infected individuals[21], individuals at higher risk were probably not identified in our population, and so no association was found between elevated alcohol consumption and the outcome. Elsewhere, excessive alcohol consumption was associated with younger age at death in $\mathrm{HCV} / \mathrm{HIV}$ co-infected individuals, which would suggest that this population is at greater risk of premature death[50].

This study has strengths and limitations. The major strength is that it is based on one of the rare cohorts of $\mathrm{HIV} / \mathrm{HCV}$ co-infected individuals combining detailed clinical follow-up data with sociobehavioral data based on yearly self-administered questionnaires. Moreover, it is one of the few studies to use a competing-risk model to investigate cause-specific mortality in the presence of competing events. The study's limitations are attributable to self-reported data, which may be a source of underreporting of some behaviors due to social desirability bias. However, previous 
studies have already shown that self-administered questionnaires capture behavioral data better than face-to-face interviews[51]. We recognize that there is no standard scale to measure cannabis use and that the available instruments focus on the assessment of cannabis misuse and disorders[52]. Accordingly, we may have underestimated cannabis consumption. Nevertheless, to minimize potential biases, we also considered the information provided in medical interviews. Although we cannot generalize our findings to all the HIV/HCV co-infected population, the HEPAVIH cohort is likely to be highly representative of co-infected individuals in France, given that the French healthcare system guarantees free access to HIV and HCV care.

Our findings bring new knowledge to clinical practice and public health promotion for $\mathrm{HIV} / \mathrm{HCV}$ co-infected individuals. Elevated coffee consumption, regular/daily cannabis use and never/past smoking were all independently associated with reduced HCV-related mortality. In contrast, severe thinness and obesity were associated with increased HCV-related, and binge drinking with increased non-HCV-related mortality. Addressing these factors may improve survival in $\mathrm{HIV} / \mathrm{HCV}$ co-infected individuals, irrespective of HCV cure.

\section{Conclusions}

HIV/HCV co-infected individuals should be advised about the benefits of coffee consumption. Tobacco cessation, as well as alcohol and weight control interventions should be routinely integrated into clinical practice and public health programs, by motivating patients to reduce risks associated with these behaviors and referring them to other specialists in the healthcare network. We recommend that further research be developed to elucidate the causal mechanisms of the factors identified in this study as being significantly associated with HCV-related and non-HCV-related mortality. Finally, considering the association between cannabis use and reduced HCV-related mortality, we believe that a more in-depth assessment of the benefits of cannabis-based therapies be carried out for the HIV/HCV co-infected population. 


\section{References}

1. Focà E, Fabbiani M, Prosperi M, Quiros Roldan E, Castelli F, Maggiolo F, et al. Liver fibrosis progression and clinical outcomes are intertwined: role of CD4+ T-cell count and NRTI exposure from a large cohort of HIV/HCV-coinfected patients with detectable HCV-RNA: A MASTER cohort study. Shang. L, editor. Medicine (Baltimore) [Internet]. Wolters Kluwer Health; 2016;95:e4091. Available from: http://www.ncbi.nlm.nih.gov/pmc/articles/PMC5265753/ 2. Rosenthal E, Roussillon C, Salmon-Céron D, Georget A, Hénard S, Huleux T, et al. Liverrelated deaths in HIV-infected patients between 1995 and 2010 in France: The Mortavic 2010 study in collaboration with the Agence Nationale de Recherche sur le SIDA (ANRS) EN 20 Mortalité 2010 survey. HIV Med. 2015;16:230-9.

3. Rallón N, García M, García-Samaniego J, Rodríguez N, Cabello A, Restrepo C, et al. HCV coinfection contributes to HIV pathogenesis by increasing immune exhaustion in CD8 T-cells. PLoS One. 2017;12:e0173943.

4. Bruno S, Di Marco V, Iavarone M, Roffi L, Boccaccio V, Crosignani A, et al. Improved survival of patients with hepatocellular carcinoma and compensated hepatitis $\mathrm{C}$ virus-related cirrhosis who attained sustained virological response. Liver Int. 2017;37:1526-34.

5. Gast KB, Tjeerdema N, Stijnen T, Smit JWA, Dekkers OM. Insulin Resistance and Risk of Incident Cardiovascular Events in Adults without Diabetes: Meta-Analysis. PLoS One [Internet]. Public Library of Science; 2012;7:e52036. Available from: https://doi.org/10.1371/journal.pone.0052036

6. Cerrato E, Calcagno A, D’Ascenzo F, Biondi-Zoccai G, Mancone M, Grosso Marra W, et al. Cardiovascular disease in HIV patients: from bench to bedside and backwards. Open Hear [Internet]. 2015;2:e000174. Available from: http://openheart.bmj.com/content/2/1/e000174.abstract 
7. Palella Jr FJ, Phair JP. Cardiovascular disease in HIV Infection. Curr Opin HIV AIDS [Internet]. 2011;6:266-71. Available from: https://www.ncbi.nlm.nih.gov/pubmed/21546831 8. Cacoub P, Dabis F, Costagliola D, Almeida K, Lert F, Piroth L, et al. Burden of HIV and hepatitis C co-infection: The changing epidemiology of hepatitis $\mathrm{C}$ in HIV-infected patients in France. Liver Int [Internet]. 2015;35:65-70. Available from:

http://www.ncbi.nlm.nih.gov/pubmed/25040895

9. Morlat P, Roussillon C, Henard S, Salmon D, Bonnet F, Cacoub P, et al. Causes of death among HIV-infected patients in France in 2010 (national survey): trends since 2000. AIDS. 2014;28:1181-91.

10. Rosenthal E, Salmon-Céron D, Lewden C, Bouteloup V, Pialoux G, Bonnet F, et al. Liverrelated deaths in HIV-infected patients between 1995 and 2005 in the French GERMIVIC Joint Study Group Network (Mortavic 2005 Study in collaboration with the Mortalité 2005 survey, ANRS EN19). HIV Med. 2009;10:282-9.

11. Lewden C, May T, Rosenthal E, Burty C, Bonnet F, Costagliola D, et al. Changes in causes of death among adults infected by HIV between 2000 and 2005: The "Mortalité 2000 and 2005" surveys (ANRS EN19 and Mortavic). J Acquir Immune Defic Syndr. 2008;48:590-8.

12. Weill-Barillet L, Pillonel J, Semaille C, Léon L, Le Strat Y, Pascal X, et al. Hepatitis C virus and HIV seroprevalences, sociodemographic characteristics, behaviors and access to syringes among drug users, a comparison of geographical areas in France, ANRS-Coquelicot 2011 survey. Rev Epidemiol Sante Publique [Internet]. 2016; Available from: http://linkinghub.elsevier.com/retrieve/pii/S0398762015004733 13. Wiessing L, Ferri M, Grady B, Kantzanou M, Sperle I, Cullen KJ, et al. Hepatitis C Virus Infection Epidemiology among People Who Inject Drugs in Europe: A Systematic Review of Data for Scaling Up Treatment and Prevention. PLoS One [Internet]. Public Library of Science; 
2014;9:e103345. Available from: https://doi.org/10.1371/journal.pone.0103345

14. Virlogeux V, Zoulim F, Pugliese P, Poizot-Martin I, Valantin MA, Cuzin L, et al. Modeling HIV-HCV coinfection epidemiology in the direct-acting antiviral era: The road to elimination.

BMC Med. BMC Medicine; 2017;15:1-11.

15. Carrieri MP, Protopopescu C, Marcellin F, Rosellini S, Wittkop L, Esterle L, et al. Protective effect of coffee consumption on all-cause mortality of French HIV-HCV co-infected patients. J Hepatol [Internet]. Elsevier; 2017;67:1157-67. Available from:

https://doi.org/10.1016/j.jhep.2017.08.005

16. Kronfli N, Bhatnagar SR, Hull MW, Moodie EEM, Cox J, Walmsley S, et al. Trends in cause-specific mortality in HIV-hepatitis C coinfection following hepatitis C treatment scale-up. AIDS. England; 2019;33:1013-1022.

17. Costiniuk CT, Brunet L, Rollet-Kurhajec KC, Cooper CL, Walmsley SL, Gill MJ, et al. Tobacco Smoking Is Not Associated With Accelerated Liver Disease in Human Immunodeficiency Virus-Hepatitis C Coinfection: A Longitudinal Cohort Analysis. Open Forum Infect Dis. United States; 2016;3:ofw050.

18. Bosetti C, Turati F, La Vecchia C. Hepatocellular carcinoma epidemiology. Best Pract Res Clin Gastroenterol [Internet]. 2014;28:753-70. Available from: http://www.sciencedirect.com/science/article/pii/S1521691814001036 19. Osna NA, Donohue TM, Kharbanda KK. Alcoholic Liver Disease: Pathogenesis and Current Management. Alcohol Res [Internet]. 2017;38:147-61. Available from: http://www.ncbi.nlm.nih.gov/pubmed/28988570\%0Ahttp://www.pubmedcentral.nih.gov/articlere nder.fcgi?artid=PMC5513682

20. Lackner C, Tiniakos D. Fibrosis and alcohol-related liver disease. J Hepatol [Internet]. Elsevier; 2019;70:294-304. Available from: https://doi.org/10.1016/j.jhep.2018.12.003 
21. Eyawo O, McGinnis KA, Justice AC, Fiellin DA, Hahn JA, Williams EC, et al. Alcohol and Mortality: Combining Self-Reported (AUDIT-C) and Biomarker Detected (PEth) Alcohol Measures Among HIV Infected and Uninfected. J Acquir Immune Defic Syndr [Internet]. 2018;77:135-43. Available from: https://www.ncbi.nlm.nih.gov/pubmed/29112041

22. Bravi F, Bosetti C, Tavani A, Gallus S, La Vecchia C. Coffee Reduces Risk for Hepatocellular Carcinoma: An Updated Meta-analysis. Clin Gastroenterol Hepatol [Internet]. Elsevier; 2013;11:1413-1421.el. Available from: https://doi.org/10.1016/j.cgh.2013.04.039 23. Carrieri MP, Serfaty L, Vilotitch A, Winnock M, Poizot-Martin I, Loko MA, et al. Cannabis use and reduced risk of insulin resistance in HIV-HCV infected patients: A longitudinal analysis (ANRS CO13 HEPAVIH). Clin Infect Dis. 2015;61:40-8.

24. Nordmann S, Vilotitch A, Roux P, Esterle L, Spire B, Marcellin F, et al. Daily cannabis and reduced risk of steatosis in human immunodeficiency virus and hepatitis $\mathrm{C}$ virus-co-infected patients (ANRS CO13-HEPAVIH). J Viral Hepat [Internet]. 2018;25:171-9. Available from: https://onlinelibrary.wiley.com/doi/abs/10.1111/jvh.12797

25. Penner EA, Buettner H, Mittleman MA. The Impact of Marijuana Use on Glucose, Insulin, and Insulin Resistance among US Adults. Am J Med [Internet]. Elsevier; 2013;126:583-9. Available from: https://doi.org/10.1016/j.amjmed.2013.03.002

26. Wijarnpreecha K, Panjawatanan P, Ungprasert P. Use of cannabis and risk of advanced liver fibrosis in patients with chronic hepatitis $\mathrm{C}$ virus infection: A systematic review and metaanalysis. J Evid Based Med [Internet]. 2018;11:272-7. Available from: https://onlinelibrary.wiley.com/doi/abs/10.1111/jebm.12317 27. Farooqui MT, Khan MA, Cholankeril G, Khan Z, Mohammed Abdul MK, Li AA, et al. Marijuana is not associated with progression of hepatic fibrosis in liver disease: a systematic review and meta-analysis. Eur J Gastroenterol Hepatol [Internet]. 2019;31:149-56. Available 
from: https://www.ncbi.nlm.nih.gov/pubmed/30234644

28. Loko M-A, Salmon D, Carrieri P, Winnock M, Mora M, Merchadou L, et al. The French national prospective cohort of patients co-infected with HIV and HCV (ANRS CO13 HEPAVIH): early findings, 2006-2010. BMC Infect Dis [Internet]. BioMed Central Ltd; 2010;10:303. Available from: http://www.biomedcentral.com/1471-2334/10/303

29. Salmon-Ceron D, Cohen J, Winnock M, Roux P, Sadr FB, Rosenthal E, et al. Engaging HIV$\mathrm{HCV}$ co-infected patients in HCV treatment: the roles played by the prescribing physician and patients' beliefs (ANRS CO13 HEPAVIH cohort, France). BMC Health Serv Res. 2012;12:59. 30. Sterling RK, Lissen E, Clumeck N, Sola R, Correa MC, Montaner J, et al. Development of a simple noninvasive index to predict significant fibrosis in patients with HIV/HCV coinfection. Hepatology. 2006;43:1317-25.

31. Roux P, Lions C, Cohen J, Winnock M, Salmon-Céron D, Bani-Sadr F, et al. Impact of HCV treatment and depressive symptoms on adherence to HAART among HIV-HCV-coinfected patients: Results from the ANRS-CO13-HEPAVIH cohort. Antivir Ther. 2014;19:171-8. 32. Fuhrer R, Rouillon F. La version française de l'échelle CES-D (Center for Epidemiologic Studies-Depression Scale). Description et traduction de l'échelle d'autoévaluation. Eur Psychiatry. Netherlands: Elsevier Science; 1989;4:163-6.

33. Bradley KA, McDonell MB, Bush K, Kivlahan DR, Diehr P, Fihn SD. The AUDIT Alcohol Consumption Questions (AUDIT-C). Arch Intern Med [Internet]. 1998;158:1789-95. Available from: http://doi.wiley.com/10.1097/00000374-199811000-00034

34. Fine JP, Gray RJ. A Proportional Hazards Model for the Subdistribution of a Competing Risk. J Am Stat Assoc [Internet]. Taylor \& Francis; 1999;94:496-509. Available from: http://amstat.tandfonline.com/doi/abs/10.1080/01621459.1999.10474144

35. Mukhopadhyay P, Rajesh M, Horváth B, Bátkai S, Park O, Tanashian G, et al. Cannabidiol 
protects against hepatic ischemia/reperfusion injury by attenuating inflammatory signaling and response, oxidative/nitrative stress, and cell death. Free Radic Biol Med. 2011;50:1368-1381. 36. Brunet L, Moodie EEM, Rollet K, Cooper C, Walmsley S, Potter M, et al. Marijuana smoking does not accelerate progression of liver disease in HIV-hepatitis C coinfection: A longitudinal Cohort analysis. Clin Infect Dis. 2013;57:663-70.

37. Adejumo AC, Adegbala OM, Adejumo KL, Bukong TN. Reduced Incidence and Better Liver Disease Outcomes among Chronic HCV Infected Patients Who Consume Cannabis. Can. J. Gastroenterol. Hepatol. 2018. p. 9430953.

38. Salmon D, Bani-Sadr F, Loko MA, Stitou H, Gervais A, Durant J, et al. Insulin resistance is associated with a higher risk of hepatocellular carcinoma in cirrhotic HIV/HCV-co-infected patients: Results from ANRS CO13 HEPAVIH. J Hepatol [Internet]. European Association for the Study of the Liver; 2012;56:862-8. Available from: http://dx.doi.org/10.1016/j.jhep.2011.11.009

39. Vara D, Salazar M, Olea-Herrero N, Guzmán M, Velasco G, Díaz-Laviada I. Anti-tumoral action of cannabinoids on hepatocellular carcinoma: role of AMPK-dependent activation of autophagy. Cell Death Differ [Internet]. 2011;18:1099-111. Available from: http://www.pubmedcentral.nih.gov/articlerender.fcgi?artid=3131949\&tool=pmcentrez\&rendertyp $\mathrm{e}=$ abstract

40. Carrieri MP, Lions C, Sogni P, Winnock M, Roux P, Mora M, et al. Association between elevated coffee consumption and daily chocolate intake with normal liver enzymes in HIV-HCV infected individuals: Results from the ANRS CO13 HEPAVIH cohort study. J Hepatol [Internet]. European Association for the Study of the Liver; 2014;60:46-53. Available from: http://dx.doi.org/10.1016/j.jhep.2013.08.014 41. Carrieri MP, Sogni P, Cohen J, Loko MA, Winnock M, Spire B, et al. Elevated coffee 
consumption and reduced risk of insulin resistance in HIV-HCV coinfected patients (HEPAVIH ANRS CO-13). Hepatology. 2012;56:2010.

42. Klein MB, Rollet-Kurhajec KC, Moodie EEM, Yaphe S, Tyndall M, Walmsley S, et al. Mortality in HIV-hepatitis C co-infected patients in Canada compared to the general Canadian population (2003-2013). AIDS. England; 2014;28:1957-65.

43. Ioannou GN, Green PK, Berry K. HCV eradication induced by direct-acting antiviral agents reduces the risk of hepatocellular carcinoma. J Hepatol [Internet]. Elsevier; 2018;68:25-32. Available from: https://doi.org/10.1016/j.jhep.2017.08.030

44. Di Angelantonio E, Bhupathiraju SN, Wormser D, Gao P, Kaptoge S, de Gonzalez AB, et al. Body-mass index and all-cause mortality: individual-participant-data meta-analysis of 239 prospective studies in four continents. Lancet [Internet]. Elsevier; 2016;388:776-86. Available from: https://doi.org/10.1016/S0140-6736(16)30175-1

45. Kee CC, Sumarni MG, Lim KH, Selvarajah S, Haniff J, Tee GHH, et al. Association of BMI with risk of CVD mortality and all-cause mortality. Public Health Nutr. Cambridge University Press; 2017;20:1226-1234.

46. Park D, Lee J-H, Han S. Underweight: another risk factor for cardiovascular disease?: A cross-sectional 2013 Behavioral Risk Factor Surveillance System (BRFSS) study of 491,773 individuals in the USA. Medicine (Baltimore) [Internet]. Wolters Kluwer Health; 2017;96:e8769-e8769. Available from: https://www.ncbi.nlm.nih.gov/pubmed/29310352 47. Laugesen K, Baggesen LM, Schmidt SAJ, Glymour MM, Lasgaard M, Milstein A, et al. Social isolation and all-cause mortality: a population-based cohort study in Denmark. Sci Rep [Internet]. 2018;8:4731. Available from: https://doi.org/10.1038/s41598-018-22963-w 48. Thomson H, Thomas S, Sellstrom E, Petticrew M. Housing improvements for health and associated socio-economic outcomes. Cochrane database Syst Rev. England; 2013;CD008657. 
49. Justice AC, McGinnis KA, Tate JP, Braithwaite RS, Bryant KJ, Cook RL, et al. Risk of mortality and physiologic injury evident with lower alcohol exposure among HIV infected compared with uninfected men. Drug Alcohol Depend. Ireland; 2016;161:95-103.

50. Marcellin P, Pequignot F, Delarocque-Astagneau E, Zarski JP, Ganne N, Hillon P, et al. Mortality related to chronic hepatitis B and chronic hepatitis C in France: Evidence for the role of HIV coinfection and alcohol consumption. J Hepatol. 2008;48:200-7.

51. Roux P, Cohen J, Lascoux-Combe C, Sogni P, Winnock M, Salmon-Ceron D, et al. Determinants of the underreporting of alcohol consumption by HIV/HCV co-infected patients during face-to-face medical interviews: The role of the physician. Drug Alcohol Depend [Internet]. Elsevier Ireland Ltd; 2011;116:228-32. Available from: http://dx.doi.org/10.1016/j.drugalcdep.2010.09.025

52. Lopez-Pelayo H, Batalla A, Balcells MM, Colom J, Gual A. Assessment of cannabis use disorders: a systematic review of screening and diagnostic instruments. Psychol Med. England; 2015;45:1121-33. 


\section{Figures}

Figure 1. Covariate-adjusted cumulative incidence function of $\mathrm{HCV}$-related deaths according to coffee intake at baseline (competing-risk regression, multivariable analysis, the ANRS

\section{CO13 HEPAVIH cohort)}




Figure 2. Covariate-adjusted cumulative incidence function of $\mathrm{HCV}$-related deaths according to cannabis use at baseline (competing-risk regression, multivariable analysis, the ANRS CO13 HEPAVIH cohort)

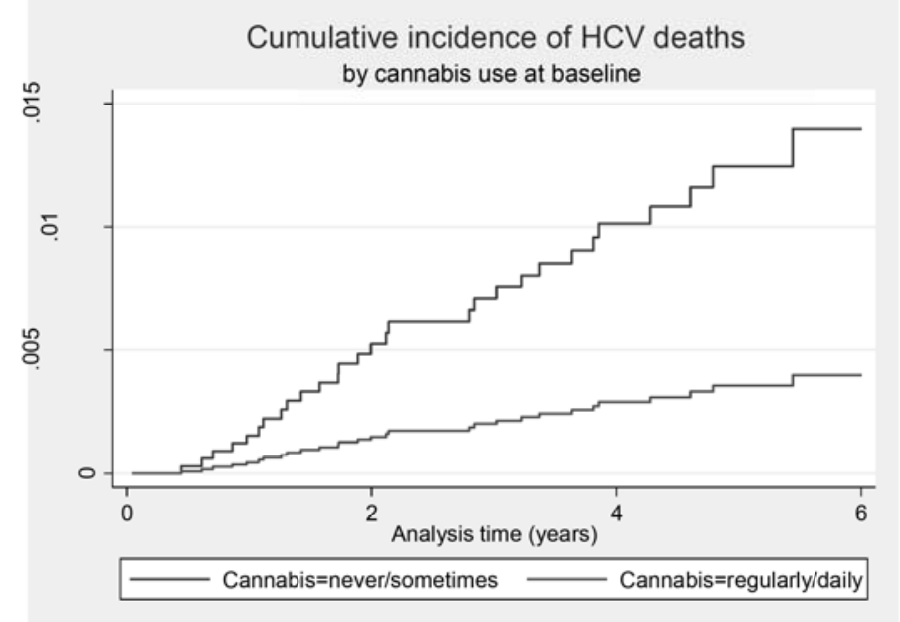


Figure 3. Covariate-adjusted cumulative incidence function of $\mathrm{HCV}$-related deaths according to smoking status at baseline (competing-risk regression, multivariable analysis, the ANRS CO13 HEPAVIH cohort)

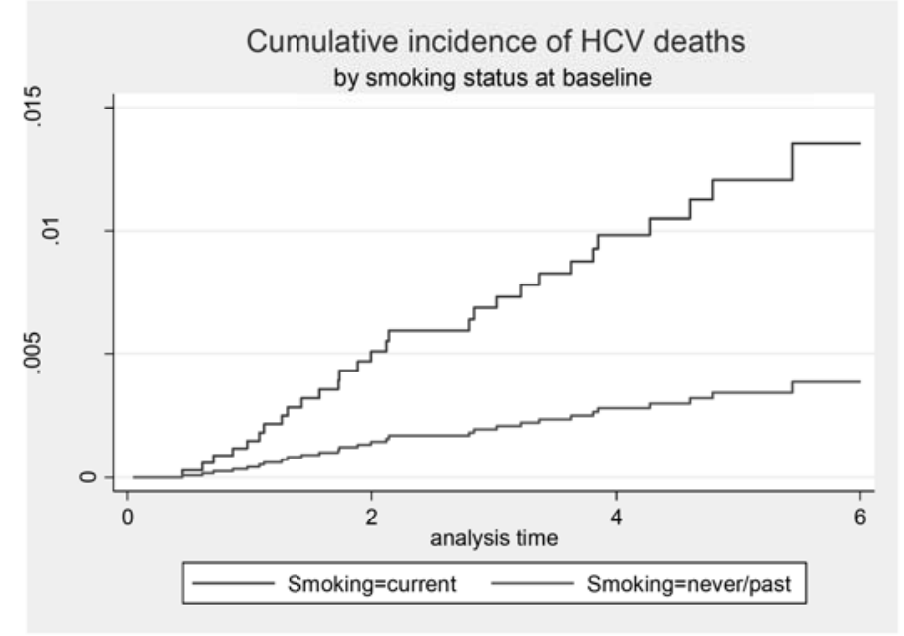




\section{Tables}

Table I. Total number of deaths by cause (the ANRS CO13 HEPAVIH cohort, $\mathbf{n = 1 , 0 2 8 )}$

\begin{tabular}{|l|c|}
\hline Total number of deaths by cause & $\mathbf{n}(\mathbf{\%})$ \\
\hline HCV-related deaths (including liver cancer) & $33(\mathbf{4 2} \cdot \mathbf{8})$ \\
Decompensated cirrhosis & $19(24 \cdot 7)$ \\
Liver cancer & $7(9 \cdot 1)$ \\
Liver cancer \& decompensated cirrhosis & $4(5 \cdot 2)$ \\
Complication of liver transplantation & $3(3 \cdot 9)$ \\
\hline Cancer-related deaths (excluding HIV- and HCV- & $\mathbf{9 ( 1 1 \cdot 7 )}$ \\
related) & $5(6 \cdot 5)$ \\
Lung and bronchial cancer & $1(1 \cdot 3)$ \\
Pancreatic cancer & $1(1 \cdot 3)$ \\
Colon cancer & $1(1 \cdot 3)$ \\
Cancer of the esophagus & $1(1 \cdot 3)$ \\
Polymetastatic Merkel carcinoma & $11(14 \cdot 3)$ \\
HIV encephalitis & $3(3 \cdot 9)$ \\
HIV-associated pulmonary arterial hypertension & $1(1 \cdot 3)$ \\
\hline HIV-related deaths & $4(5 \cdot 2)$ \\
\hline Deaths from other causes & $1(1 \cdot 3)$ \\
\hline Hodive multifocal leukoencephalopathy & $\mathbf{2 7}(\mathbf{3 5} \cdot \mathbf{1})$ \\
\hline
\end{tabular}




\begin{tabular}{|l|c|} 
Overdose & $3(3 \cdot 9)$ \\
Suicide & $3(3 \cdot 9)$ \\
Respiratory diseases & $2(2 \cdot 6)$ \\
Unexplained sudden death & $2(2 \cdot 6)$ \\
Infectious and parasitic diseases & $1(1 \cdot 3)$ \\
Digestive diseases & $1(1 \cdot 3)$ \\
Endocrine, nutritional and metabolic diseases & $1(1 \cdot 3)$ \\
\hline Total & $\mathbf{7 7 ( 1 0 0 )}$ \\
\hline
\end{tabular}


Table II. Characteristics of the study population measured at last available follow-up visit according to specific causes of death (the ANRS CO13 HEPAVIH cohort, $n=1,028$ )

\begin{tabular}{|c|c|c|c|c|c|c|c|}
\hline & & $\begin{array}{l}\text { n (\%) of } \\
\text { patients }\end{array}$ & $\begin{array}{l}\text { HCV- } \\
\text { related } \\
\text { deaths } \\
(n=33)\end{array}$ & $\begin{array}{l}\text { HIV- } \\
\text { related } \\
\text { deaths } \\
(\mathrm{n}=8)\end{array}$ & $\begin{array}{c}\text { Cancer } \\
- \\
\text { related } \\
\text { deaths } \\
(\mathrm{n}=9)\end{array}$ & $\begin{array}{l}\text { Deaths } \\
\text { from } \\
\text { other } \\
\text { causes } \\
(n=27)\end{array}$ & $\begin{array}{l}\text { Total } \\
\text { deaths } \\
(n=77)\end{array}$ \\
\hline Gender & $\begin{array}{l}\text { Male } \\
\text { Female }\end{array}$ & $\begin{array}{l}722(70 \cdot 2) \\
306(29 \cdot 8)\end{array}$ & $\begin{array}{l}29 \\
4\end{array}$ & $\begin{array}{l}5 \\
3\end{array}$ & $\begin{array}{l}5 \\
4\end{array}$ & $\begin{array}{c}22 \\
5\end{array}$ & $\begin{array}{l}61 \\
16\end{array}$ \\
\hline Age $(\text { years })^{\S}$ & $\begin{array}{l}18-39 \\
40-49 \\
50+\end{array}$ & $\begin{array}{c}50(4 \cdot 9) \\
531(51 \cdot 6) \\
447(43 \cdot 5)\end{array}$ & $\begin{array}{c}1 \\
18 \\
14\end{array}$ & $\begin{array}{l}0 \\
7 \\
1\end{array}$ & $\begin{array}{l}0 \\
4 \\
5\end{array}$ & $\begin{array}{l}1 \\
19 \\
7\end{array}$ & $\begin{array}{c}2 \\
48 \\
27\end{array}$ \\
\hline Age $(\text { years })^{\S}$ & Median [IQR] & $49[46-52]$ & $\begin{array}{l}48 \\
{[45-} \\
52]\end{array}$ & $\begin{array}{l}45 \\
{[44-} \\
47]\end{array}$ & $\begin{array}{l}50 \\
{[46-} \\
53]\end{array}$ & $\begin{array}{c}48 \\
{[43-} \\
50]\end{array}$ & $\begin{array}{c}48 \\
{[44-51]}\end{array}$ \\
\hline $\begin{array}{l}\text { Having a } \\
\text { steady partner }\end{array}$ & $\begin{array}{l}\text { No } \\
\text { Yes } \\
\text { Missing }\end{array}$ & $\begin{array}{c}395(38 \cdot 4) \\
628(61 \cdot 1) \\
5(0 \cdot 5)\end{array}$ & $\begin{array}{c}16 \\
17 \\
0\end{array}$ & $\begin{array}{l}6 \\
2 \\
0\end{array}$ & $\begin{array}{l}5 \\
4 \\
0\end{array}$ & $\begin{array}{c}13 \\
14 \\
0\end{array}$ & $\begin{array}{c}40 \\
37 \\
0\end{array}$ \\
\hline $\begin{array}{l}\text { Being } \\
\text { employed }^{\S}\end{array}$ & $\begin{array}{l}\text { No } \\
\text { Yes } \\
\text { Missing }\end{array}$ & $\begin{array}{c}536(52 \cdot 1) \\
487(47 \cdot 4) \\
5(0 \cdot 5)\end{array}$ & $\begin{array}{l}25 \\
8 \\
0\end{array}$ & $\begin{array}{l}4 \\
4 \\
0\end{array}$ & $\begin{array}{l}5 \\
4 \\
0\end{array}$ & $\begin{array}{l}20 \\
7 \\
0\end{array}$ & $\begin{array}{c}54 \\
23 \\
0\end{array}$ \\
\hline $\begin{array}{l}\text { Having } \\
\text { children }\end{array}$ & $\begin{array}{l}\text { No } \\
\text { Yes } \\
\text { Missing }\end{array}$ & $\begin{array}{c}715(69 \cdot 5) \\
310(30 \cdot 2) \\
3(0 \cdot 3)\end{array}$ & $\begin{array}{l}24 \\
9 \\
0\end{array}$ & $\begin{array}{l}8 \\
0 \\
0\end{array}$ & $\begin{array}{l}6 \\
3 \\
0\end{array}$ & $\begin{array}{l}22 \\
4 \\
1\end{array}$ & $\begin{array}{l}60 \\
16 \\
1\end{array}$ \\
\hline
\end{tabular}




\begin{tabular}{|c|c|c|c|c|c|c|c|}
\hline $\begin{array}{l}\text { Comfortable } \\
\text { housing }\end{array}$ & $\begin{array}{l}\text { No } \\
\text { Yes } \\
\text { Missing }\end{array}$ & $\begin{array}{c}166(16 \cdot 1) \\
860(83 \cdot 7) \\
2(0 \cdot 2)\end{array}$ & $\begin{array}{l}8 \\
25 \\
0\end{array}$ & 1 & 1 & $\begin{array}{l}12 \\
15 \\
0\end{array}$ & 55 \\
\hline $\begin{array}{l}\text { Unstable } \\
\text { housing }^{\S \mathrm{a}}\end{array}$ & $\begin{array}{l}\text { No } \\
\text { Yes } \\
\text { Missing }\end{array}$ & $\begin{array}{c}1006(97 \cdot 9) \\
18(1 \cdot 7) \\
4(0 \cdot 4)\end{array}$ & $\begin{array}{l}30 \\
3 \\
0\end{array}$ & $\begin{array}{l}0 \\
0\end{array}$ & 8 & $\begin{array}{l}25 \\
2 \\
0\end{array}$ & $\begin{array}{l}71 \\
6 \\
0\end{array}$ \\
\hline HCV genotype & $\begin{array}{l}1 / 4 \\
2 / 3 \\
\text { Missing }\end{array}$ & $\begin{array}{c}755(73 \cdot 4) \\
260(25 \cdot 3) \\
13(1 \cdot 3)\end{array}$ & $\begin{array}{l}30 \\
3 \\
0\end{array}$ & 3 & 7 & $\begin{array}{l}19 \\
8 \\
0\end{array}$ & $\begin{array}{l}61 \\
16 \\
0\end{array}$ \\
\hline $\begin{array}{l}\text { Post-treatment } \\
\text { HCV cure }\end{array}$ & $\begin{array}{l}\text { No } \\
\text { Yes }\end{array}$ & $\begin{array}{l}781(76 \cdot 0) \\
247(24 \cdot 0)\end{array}$ & $\begin{array}{l}32 \\
1\end{array}$ & 8 & 9 & $\begin{array}{l}24 \\
3\end{array}$ & 73 \\
\hline $\begin{array}{l}\text { Severe fibrosis } \\
(\text { FIB-4>3·25) }\end{array}$ & $\begin{array}{l}\text { No } \\
\text { Yes } \\
\text { Missing }\end{array}$ & $\begin{array}{c}844(82 \cdot 1) \\
162(15 \cdot 8) \\
22(2 \cdot 1)\end{array}$ & $\begin{array}{l}9 \\
22 \\
2\end{array}$ & 7 & 1 & $\begin{array}{l}21 \\
4 \\
2\end{array}$ & $\begin{array}{r}40 \\
27 \\
2\end{array}$ \\
\hline $\begin{array}{l}\text { History of } \\
\text { HCC and/or } \\
\text { liver } \\
\text { transplantation } \\
\text { at enrollment }{ }^{\S \S}\end{array}$ & $\begin{array}{l}\text { No } \\
\text { Yes }\end{array}$ & $\begin{array}{c}997(97 \cdot 0) \\
31(3 \cdot 0)\end{array}$ & $\begin{array}{l}17 \\
16\end{array}$ & 1 & 0 & $\begin{array}{l}25 \\
2\end{array}$ & 58 \\
\hline $\begin{array}{l}\text { History of } \\
\text { indirect clinical } \\
\text { signs of } \\
\text { cirrhosis at } \\
\text { enrollment }{ }^{\S \S b}\end{array}$ & $\begin{array}{l}\text { No } \\
\text { Yes }\end{array}$ & $\begin{array}{c}998(97 \cdot 1) \\
30(2 \cdot 9)\end{array}$ & $\begin{array}{l}22 \\
11\end{array}$ & 1 & 9 & $\begin{array}{c}26 \\
1\end{array}$ & 13 \\
\hline
\end{tabular}




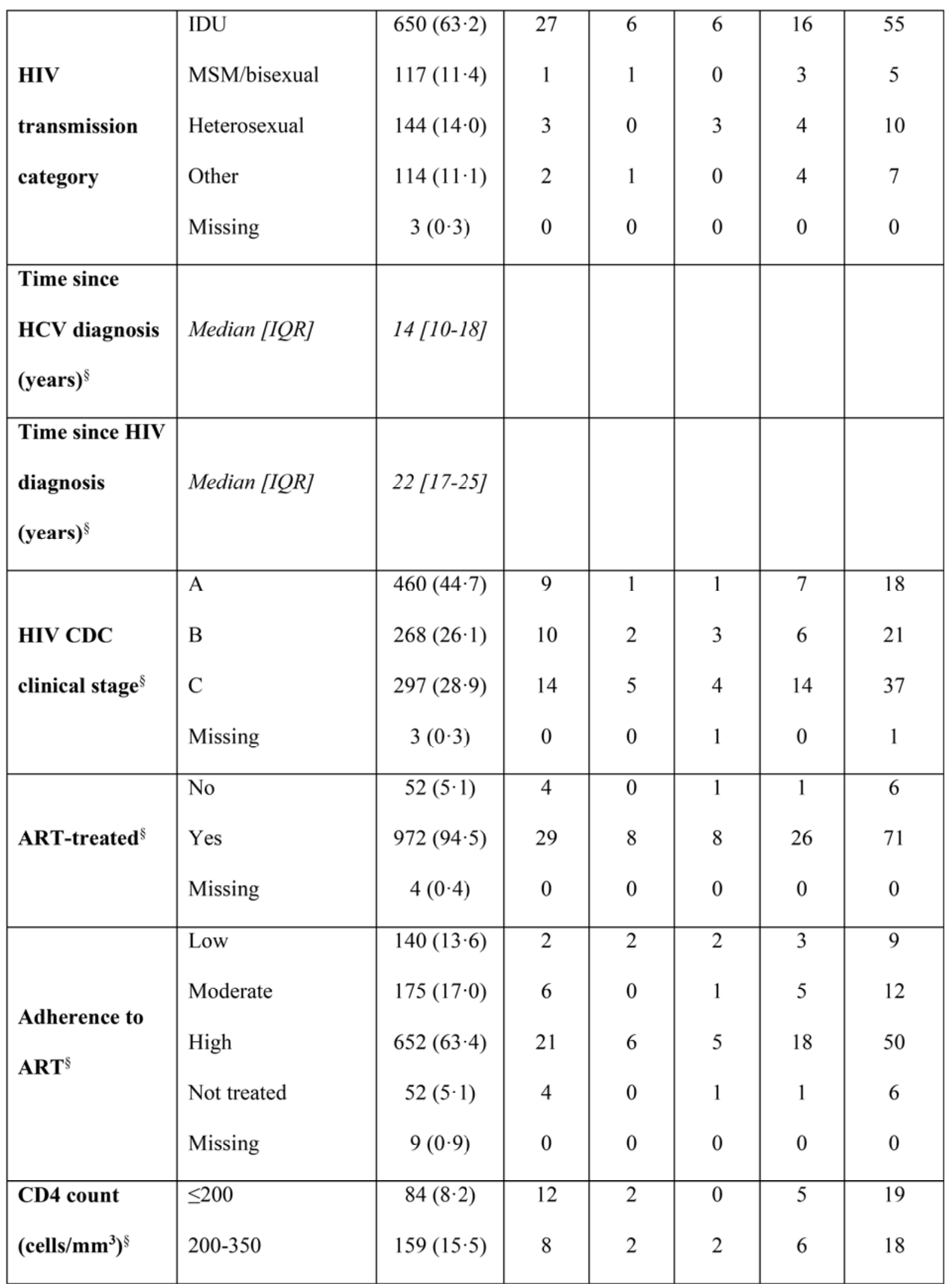




\begin{tabular}{|c|c|c|c|c|c|c|c|}
\hline & $\begin{array}{l}350-500 \\
>500\end{array}$ & $\begin{array}{l}219(21 \cdot 3) \\
566(55 \cdot 1)\end{array}$ & $\begin{array}{l}6 \\
7\end{array}$ & 2 & 1 & $\begin{array}{c}5 \\
5 \\
11\end{array}$ & $\begin{array}{l}14 \\
26\end{array}$ \\
\hline $\begin{array}{l}\text { Depressive } \\
\text { symptoms }^{\text {sc }}\end{array}$ & $\begin{array}{l}\text { No } \\
\text { Yes } \\
\text { Missing }\end{array}$ & $\begin{array}{c}612(59 \cdot 5) \\
375(36 \cdot 5) \\
41(4 \cdot 0)\end{array}$ & $\begin{array}{l}15 \\
14 \\
4\end{array}$ & 4 & 6 & $\begin{array}{l}13 \\
12 \\
2\end{array}$ & $\begin{array}{c}38 \\
33 \\
6\end{array}$ \\
\hline $\begin{array}{l}\text { Smoking status } \\
\text { at baseline }{ }^{\S \S}\end{array}$ & $\begin{array}{l}\text { Never/past } \\
\text { Current } \\
\text { Missing }\end{array}$ & $\begin{array}{c}272(26 \cdot 5) \\
738(71 \cdot 8) \\
18(1 \cdot 7)\end{array}$ & $\begin{array}{c}8 \\
24 \\
1\end{array}$ & 2 & 1 & $\begin{array}{c}4 \\
22 \\
1\end{array}$ & $\begin{array}{l}15 \\
59 \\
3\end{array}$ \\
\hline $\begin{array}{l}\text { Alcohol } \\
\text { consumption at } \\
\text { baseline }^{\S \S d}\end{array}$ & $\begin{array}{l}\text { No consumption } \\
\text { Low } \\
\text { Moderate } \\
\text { Elevated } \\
\text { Missing }\end{array}$ & $\begin{array}{c}256(24 \cdot 9) \\
502(48 \cdot 8) \\
183(17 \cdot 8) \\
61(5 \cdot 9) \\
26(2 \cdot 5)\end{array}$ & $\begin{array}{l}11 \\
9 \\
8 \\
4 \\
1\end{array}$ & 2 & 3 & $\begin{array}{l}8 \\
12 \\
3\end{array}$ & $\begin{array}{l}24 \\
28 \\
13 \\
10 \\
2\end{array}$ \\
\hline $\begin{array}{l}\text { Regular binge } \\
\text { drinking at } \\
\text { baseline }^{\S \S \mathrm{e}}\end{array}$ & $\begin{array}{l}\text { No } \\
\text { Yes } \\
\text { Missing }\end{array}$ & $\begin{array}{c}842(81 \cdot 9) \\
143(13 \cdot 9) \\
43(4 \cdot 2)\end{array}$ & $\begin{array}{l}26 \\
5 \\
2\end{array}$ & 6 & 7 & $\begin{array}{l}16 \\
9 \\
2\end{array}$ & $\begin{array}{c}55 \\
18 \\
4\end{array}$ \\
\hline $\begin{array}{l}\text { Coffee intake } \\
\text { at baseline } e^{\S \S f}\end{array}$ & $\begin{array}{l}\text { Low } \\
\text { Moderate } \\
\text { Elevated }\end{array}$ & $\begin{array}{l}527(51 \cdot 3) \\
227(22 \cdot 1) \\
274(26 \cdot 6)\end{array}$ & $\begin{array}{l}24 \\
6 \\
3\end{array}$ & 5 & 5 & $\begin{array}{l}11 \\
11\end{array}$ & $\begin{array}{l}45 \\
21 \\
11\end{array}$ \\
\hline $\begin{array}{l}\text { Cannabis use } \\
\text { at baseline }{ }^{\S \S}\end{array}$ & $\begin{array}{l}\text { Never } \\
\text { Sometimes } \\
\text { Regularly/daily } \\
\text { Missing }\end{array}$ & $\begin{array}{c}471(45 \cdot 8) \\
203(19 \cdot 7) \\
255(24 \cdot 8) \\
99(9 \cdot 6)\end{array}$ & $\begin{array}{l}17 \\
9 \\
4 \\
3\end{array}$ & 2 & 3 & 10 & $\begin{array}{l}32 \\
18\end{array}$ \\
\hline
\end{tabular}




\begin{tabular}{|c|c|c|c|c|c|c|c|}
\hline Non-prescribed & No & $907(88 \cdot 2)$ & 28 & 7 & 9 & 21 & 65 \\
\hline opioid use at & Yes & $37(3 \cdot 6)$ & 2 & 0 & 0 & 2 & 4 \\
\hline baseline $^{\S \S}$ & Missing & $84(8 \cdot 2)$ & 3 & 1 & 0 & 4 & 8 \\
\hline Stimulant drug & No & $857(83 \cdot 4)$ & 29 & 7 & 9 & 20 & 65 \\
\hline use at & Yes & $87(8 \cdot 5)$ & 1 & 0 & 0 & 3 & 4 \\
\hline baseline $^{\S \S}$ & Missing & $84(8 \cdot 2)$ & 3 & 1 & 0 & 4 & 8 \\
\hline \multirow{6}{*}{$\begin{array}{l}\text { Body mass } \\
\text { index status }^{\S}\end{array}$} & $\begin{array}{l}\text { Severely thin } \\
(\mathrm{BMI}<16)\end{array}$ & $19(1 \cdot 8)$ & 2 & 0 & 1 & 0 & 3 \\
\hline & $\begin{array}{l}\text { Underweight (BMI: } \\
16-18 \cdot 49)\end{array}$ & $110(10 \cdot 7)$ & 2 & 2 & 2 & 1 & 7 \\
\hline & $\begin{array}{l}\text { Normal weight } \\
\text { (BMI: 18·5-24.99) }\end{array}$ & $658(64 \cdot 0)$ & 21 & 3 & 6 & 18 & 48 \\
\hline & $\begin{array}{l}\text { Overweight (BMI: } \\
\text { 25-29.99) }\end{array}$ & $192(18 \cdot 7)$ & 4 & 3 & 0 & 6 & 13 \\
\hline & Obese $(\mathrm{BMI} \geq 30)$ & $48(4 \cdot 7)$ & 4 & 0 & 0 & 2 & 6 \\
\hline & Missing & $1(0 \cdot 1)$ & 0 & 0 & 0 & 0 & 0 \\
\hline
\end{tabular}

$\mathrm{CI}=$ confidence interval; IQR=interquartile range.

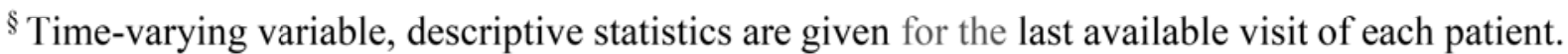

${ }^{\S \S}$ Fixed variable, measured at baseline (i.e. at the first available visit of each patient).

${ }^{a}$ Patients who reported living in hotels, accommodation centers, on the street or in therapeutic apartments were considered to have unstable housing.

${ }^{b}$ The presence of indirect clinical signs of cirrhosis was defined by one of the following: ascites, esophageal varices with or without bleeding, hepatic encephalopathy.

${ }^{c}$ Patients with a CES-D score $\geq 17(23)$ for men(women) were considered to have depressive symptoms. 
${ }^{\mathrm{d}}$ The following categories were used for average daily alcohol consumption: no consumption, low ( $\leq 1$ alcohol unit (AU)/day), moderate (1-3 AU/day for women, and 1-4 AU/day for men), and elevated ( $>3 \mathrm{AU} /$ day for women, and $>4 \mathrm{AU} /$ day for men).

${ }^{\mathrm{e}}$ Regular binge drinking was defined as drinking at least $5 \mathrm{AU}$ on one occasion at least once a week.

${ }^{\mathrm{f}}$ We used the following categories for average daily coffee intake: low ( $\leq 1 \mathrm{cups} /$ day), moderate (2 cups/day), and elevated ( $\geq 3$ cups/day). 
Table III. Factors associated with HCV-related and non-HCV-related mortality (competing-risk regression models, univariable analyses, the ANRS CO13 HEPAVIH cohort, $n=1,028$ patients, $N=4,579$ visits)

\begin{tabular}{|c|c|c|c|c|c|}
\hline & & \multicolumn{2}{|c|}{ HCV-related mortality } & \multicolumn{2}{|c|}{$\begin{array}{c}\text { Non-HCV-related } \\
\text { mortality }\end{array}$} \\
\hline & & SHR $[95 \%$ CI] & $\begin{array}{c}\text { p- } \\
\text { value }\end{array}$ & SHR $[95 \% \mathrm{CI}]$ & $\begin{array}{c}\text { p- } \\
\text { value }\end{array}$ \\
\hline Gender & $\begin{array}{l}\text { Male (ref) } \\
\text { Female }\end{array}$ & $\begin{array}{c}1 \\
0 \cdot 32[0 \cdot 11-0 \cdot 92]\end{array}$ & $0 \cdot 034$ & $\begin{array}{c}1 \\
0 \cdot 88[0 \cdot 45-1 \cdot 71]\end{array}$ & $0 \cdot 710$ \\
\hline Age $\left(\right.$ years) ${ }^{\S}$ & $\begin{array}{l}18-39 \\
40-49 \text { (ref) } \\
50+\end{array}$ & $\begin{array}{c}0 \cdot 44[0 \cdot 06-3 \cdot 33] \\
1 \\
1 \cdot 48[0 \cdot 73-3 \cdot 02]\end{array}$ & $\begin{array}{l}0 \cdot 431 \\
0 \cdot 274\end{array}$ & $\begin{array}{c}0 \cdot 27[0 \cdot 04-2 \cdot 01] \\
1 \\
0 \cdot 74[0 \cdot 38-1 \cdot 42]\end{array}$ & $\begin{array}{l}0 \cdot 202 \\
0 \cdot 365\end{array}$ \\
\hline Age (years) ${ }^{\S}$ & & $1 \cdot 03[0 \cdot 99-1 \cdot 08]$ & $0 \cdot 142$ & $1 \cdot 02[0 \cdot 97-1 \cdot 07]$ & $0 \cdot 455$ \\
\hline $\begin{array}{l}\text { Having a } \\
\text { steady partner }\end{array}$ & $\begin{array}{l}\text { No (ref) } \\
\text { Yes }\end{array}$ & $\begin{array}{c}1 \\
0 \cdot 63[0 \cdot 32-1 \cdot 25]\end{array}$ & $0 \cdot 185$ & $\begin{array}{c}1 \\
0 \cdot 49[0 \cdot 27-0 \cdot 89]\end{array}$ & $0 \cdot 020$ \\
\hline $\begin{array}{l}\text { Being } \\
\text { employed }^{\S}\end{array}$ & $\begin{array}{l}\text { No (ref) } \\
\text { Yes }\end{array}$ & $\begin{array}{c}1 \\
0 \cdot 33[0 \cdot 15-0 \cdot 73]\end{array}$ & $0 \cdot 006$ & $\begin{array}{c}1 \\
0 \cdot 54[0 \cdot 29-1 \cdot 02]\end{array}$ & $0 \cdot 057$ \\
\hline $\begin{array}{l}\text { Having } \\
\text { children }^{\S}\end{array}$ & $\begin{array}{l}\text { No (ref) } \\
\text { Yes }\end{array}$ & $\begin{array}{c}1 \\
0 \cdot 79[0 \cdot 37-1 \cdot 70]\end{array}$ & $0 \cdot 546$ & $\begin{array}{c}1 \\
0 \cdot 40[0 \cdot 18-0 \cdot 91]\end{array}$ & 0.028 \\
\hline $\begin{array}{l}\text { Comfortable } \\
\text { housing }^{\S}\end{array}$ & $\begin{array}{l}\text { No (ref) } \\
\text { Yes }\end{array}$ & $\begin{array}{c}1 \\
0 \cdot 62[0 \cdot 28-1 \cdot 37]\end{array}$ & $0 \cdot 242$ & $\begin{array}{c}1 \\
0 \cdot 42[0 \cdot 22-0 \cdot 78]\end{array}$ & $0 \cdot 007$ \\
\hline $\begin{array}{l}\text { Unstable } \\
\text { housing }^{\text {§a }}\end{array}$ & $\begin{array}{l}\text { No (ref) } \\
\text { Yes }\end{array}$ & $\begin{array}{c}1 \\
5 \cdot 22[1 \cdot 67-16 \cdot 3]\end{array}$ & $0 \cdot 004$ & $\begin{array}{c}1 \\
4 \cdot 09[1 \cdot 27-13 \cdot 2]\end{array}$ & $0 \cdot 018$ \\
\hline HCV genotype & $\begin{array}{l}1 / 4 \text { (ref) } \\
2 / 3\end{array}$ & $\begin{array}{c}1 \\
0 \cdot 29[0 \cdot 09-0 \cdot 95]\end{array}$ & $0 \cdot 040$ & $\begin{array}{c}1 \\
1 \cdot 24[0 \cdot 65-2 \cdot 37]\end{array}$ & $0 \cdot 516$ \\
\hline
\end{tabular}




\begin{tabular}{|c|c|c|c|c|c|}
\hline $\begin{array}{l}\text { Post-treatment } \\
\text { HCV cure }\end{array}$ & $\begin{array}{l}\text { No (ref) } \\
\text { Yes }\end{array}$ & $\begin{array}{c}1 \\
0 \cdot 12[0 \cdot 02-0 \cdot 88]\end{array}$ & 0.037 & $\begin{array}{c}1 \\
0 \cdot 27[0 \cdot 08-0 \cdot 85]\end{array}$ & 0.025 \\
\hline $\begin{array}{l}\text { Severe fibrosis } \\
(\text { FIB-4>3.25) }\end{array}$ & $\begin{array}{l}\text { No (ref) } \\
\text { Yes }\end{array}$ & $\begin{array}{c}1 \\
13 \cdot 33[6 \cdot 13- \\
29 \cdot 0]\end{array}$ & $<10^{-3}$ & $\begin{array}{c}1 \\
0 \cdot 60[0 \cdot 24-1 \cdot 51]\end{array}$ & $0 \cdot 280$ \\
\hline $\begin{array}{l}\text { History of } \\
\text { HCC and/or } \\
\text { liver } \\
\text { transplantation } \\
\text { at enrollment }{ }^{\S \S}\end{array}$ & $\begin{array}{l}\text { No (ref) } \\
\text { Yes }\end{array}$ & $\begin{array}{c}1 \\
38 \cdot 9[19 \cdot 6-76 \cdot 9]\end{array}$ & $<10^{-3}$ & $\begin{array}{c}1 \\
2 \cdot 21[0 \cdot 70-6 \cdot 94]\end{array}$ & $0 \cdot 173$ \\
\hline $\begin{array}{l}\text { History of } \\
\text { indirect clinical } \\
\text { signs of } \\
\text { cirrhosis at } \\
\text { enrollment }^{\S \S b}\end{array}$ & $\begin{array}{l}\text { No (ref) } \\
\text { Yes }\end{array}$ & $\begin{array}{c}1 \\
20 \cdot 4[9 \cdot 97-41 \cdot 7]\end{array}$ & $<10^{-3}$ & $\begin{array}{c}1 \\
1 \cdot 57[0 \cdot 39-6 \cdot 29]\end{array}$ & $0 \cdot 521$ \\
\hline $\begin{array}{l}\text { HIV } \\
\text { transmission } \\
\text { category }\end{array}$ & $\begin{array}{l}\text { IDU (ref) } \\
\text { MSM/bisexual } \\
\text { Heterosexual } \\
\text { Other }\end{array}$ & $\begin{array}{c}1 \\
0 \cdot 21[0 \cdot 03-1 \cdot 52] \\
0 \cdot 49[0 \cdot 15-1 \cdot 61] \\
0 \cdot 40[0 \cdot 09-1 \cdot 70]\end{array}$ & $\begin{array}{l}0 \cdot 121 \\
0 \cdot 239 \\
0 \cdot 216\end{array}$ & $\begin{array}{c}1 \\
0 \cdot 81[0 \cdot 29-2 \cdot 32] \\
1 \cdot 10[0 \cdot 48-2 \cdot 53] \\
0 \cdot 96[0 \cdot 37-2 \cdot 49]\end{array}$ & $\begin{array}{l}0 \cdot 700 \\
0 \cdot 816 \\
0 \cdot 940\end{array}$ \\
\hline $\begin{array}{l}\text { Time since } \\
\text { HCV diagnosis } \\
\text { (years) }^{\S}\end{array}$ & & $0 \cdot 96[0 \cdot 90-1 \cdot 02]$ & $0 \cdot 221$ & $1 \cdot 00[0 \cdot 95-1 \cdot 05]$ & 0.922 \\
\hline $\begin{array}{l}\text { Time since HIV } \\
\text { diagnosis } \\
\text { (years) }^{\S}\end{array}$ & & $1 \cdot 00[0 \cdot 96-1 \cdot 04]$ & 0.946 & $0 \cdot 98[0 \cdot 94-1 \cdot 03]$ & $0 \cdot 433$ \\
\hline
\end{tabular}




\begin{tabular}{|c|c|c|c|c|c|}
\hline $\begin{array}{l}\text { HIV CDC } \\
\text { clinical stage }\end{array}$ & $\begin{array}{l}\text { A/B (ref) } \\
\text { C }\end{array}$ & $\begin{array}{c}1 \\
1 \cdot 87[0 \cdot 94-3 \cdot 73]\end{array}$ & 0.073 & $\begin{array}{c}1 \\
2 \cdot 95[1 \cdot 62-5 \cdot 36]\end{array}$ & $<10^{-3}$ \\
\hline ART-treated ${ }^{\S}$ & $\begin{array}{l}\text { No (ref) } \\
\text { Yes }\end{array}$ & $\begin{array}{c}1 \\
0 \cdot 46[0 \cdot 16-1 \cdot 32]\end{array}$ & $0 \cdot 150$ & $\begin{array}{c}1 \\
1 \cdot 32[0 \cdot 32-5 \cdot 47]\end{array}$ & $0 \cdot 698$ \\
\hline $\begin{array}{l}\text { Adherence to } \\
\text { ART }^{\S}\end{array}$ & $\begin{array}{l}\text { Low (ref) } \\
\text { Moderate } \\
\text { High } \\
\text { Not treated }\end{array}$ & $\begin{array}{c}1 \\
1 \cdot 66[0 \cdot 35-7 \cdot 89] \\
1 \cdot 65[0 \cdot 40-6 \cdot 84] \\
3 \cdot 42[0 \cdot 64-18 \cdot 3]\end{array}$ & $\begin{array}{l}0 \cdot 526 \\
0 \cdot 486 \\
0 \cdot 151\end{array}$ & $\begin{array}{c}1 \\
0 \cdot 49[0 \cdot 16-1 \cdot 45] \\
0 \cdot 67[0 \cdot 30-1 \cdot 52] \\
0 \cdot 51[0 \cdot 11-2 \cdot 41]\end{array}$ & $\begin{array}{l}0 \cdot 199 \\
0 \cdot 342 \\
0.393\end{array}$ \\
\hline $\begin{array}{l}\text { CD4 count } \\
\left(\text { cells } / \mathbf{m m}^{3}\right)^{\S}\end{array}$ & $\begin{array}{l}>500 \text { (ref) } \\
350-500 \\
200-350 \\
\leq 200\end{array}$ & $\begin{array}{c}1 \\
2 \cdot 01[0 \cdot 68-5 \cdot 95] \\
3 \cdot 23[1 \cdot 17-8 \cdot 89] \\
11 \cdot 2[4 \cdot 47-28 \cdot 3]\end{array}$ & $\begin{array}{l}0 \cdot 204 \\
0 \cdot 023 \\
<10^{-3}\end{array}$ & $\begin{array}{c}1 \\
1 \cdot 01[0 \cdot 44-2 \cdot 29] \\
1 \cdot 52[0 \cdot 71-3 \cdot 28] \\
2 \cdot 29[0 \cdot 96-5 \cdot 45]\end{array}$ & $\begin{array}{r}0 \cdot 983 \\
0 \cdot 281 \\
0 \cdot 060\end{array}$ \\
\hline $\begin{array}{l}\text { Depressive } \\
\text { symptoms }^{\text {sc }}\end{array}$ & $\begin{array}{l}\text { No (ref) } \\
\text { Yes }\end{array}$ & $\begin{array}{c}1 \\
1 \cdot 48[0 \cdot 71-3 \cdot 06]\end{array}$ & $0 \cdot 290$ & $\begin{array}{c}1 \\
1 \cdot 30[0 \cdot 71-2 \cdot 38]\end{array}$ & $0 \cdot 401$ \\
\hline $\begin{array}{l}\text { Smoking status } \\
\text { at baseline }^{\S \S}\end{array}$ & $\begin{array}{l}\text { Current (ref) } \\
\text { Never/past }\end{array}$ & $\begin{array}{c}1 \\
0 \cdot 87[0 \cdot 39-1 \cdot 94]\end{array}$ & 0.733 & $\begin{array}{c}1 \\
0 \cdot 51[0 \cdot 23-1 \cdot 15]\end{array}$ & $0 \cdot 107$ \\
\hline $\begin{array}{l}\text { Alcohol } \\
\text { consumption at } \\
\text { baseline }^{\S \S d}\end{array}$ & $\begin{array}{l}\text { No consumption (ref) } \\
\text { Low } \\
\text { Moderate } \\
\text { Elevated }\end{array}$ & $\begin{array}{c}1 \\
0 \cdot 42[0 \cdot 17-1 \cdot 01] \\
1 \cdot 02[0 \cdot 41-2 \cdot 52] \\
1 \cdot 55[0 \cdot 49-4 \cdot 87]\end{array}$ & $\begin{array}{l}0.052 \\
0.971 \\
0.452\end{array}$ & $\begin{array}{c}1 \\
0 \cdot 75[0 \cdot 37-1 \cdot 51] \\
0 \cdot 54[0 \cdot 19-1 \cdot 50] \\
2 \cdot 00[0 \cdot 76-5 \cdot 26]\end{array}$ & $\begin{array}{l}0 \cdot 419 \\
0 \cdot 238 \\
0 \cdot 159\end{array}$ \\
\hline $\begin{array}{l}\text { Regular binge } \\
\text { drinking at } \\
\text { baseline }^{\S \S \mathrm{e}}\end{array}$ & $\begin{array}{l}\text { No (ref) } \\
\text { Yes }\end{array}$ & $\begin{array}{c}1 \\
1 \cdot 11[0 \cdot 42-2 \cdot 88]\end{array}$ & 0.834 & $\begin{array}{c}1 \\
2 \cdot 66[1 \cdot 38-5 \cdot 11]\end{array}$ & $0 \cdot 003$ \\
\hline $\begin{array}{l}\text { Coffee intake } \\
\text { at baseline } e^{\S \S f}\end{array}$ & $\begin{array}{l}\text { Low/moderate (ref) } \\
\text { Elevated }\end{array}$ & $\begin{array}{c}1 \\
0 \cdot 27[0 \cdot 08-0 \cdot 88]\end{array}$ & 0.030 & $\begin{array}{c}1 \\
0 \cdot 60[0 \cdot 28-1 \cdot 30]\end{array}$ & $0 \cdot 199$ \\
\hline
\end{tabular}




\begin{tabular}{|c|c|c|c|c|c|}
\hline $\begin{array}{l}\text { Cannabis use } \\
\text { at baseline }^{\S \S}\end{array}$ & $\begin{array}{l}\text { Never/sometimes (ref) } \\
\text { Regularly/daily }\end{array}$ & $\begin{array}{c}1 \\
0 \cdot 39[0 \cdot 13-1 \cdot 11]\end{array}$ & 0.077 & $\begin{array}{c}1 \\
1 \cdot 50[0 \cdot 77-2 \cdot 92]\end{array}$ & $0 \cdot 228$ \\
\hline $\begin{array}{l}\text { Non-prescribed } \\
\text { opioid use at } \\
\text { baseline }^{\S \S}\end{array}$ & $\begin{array}{l}\text { No (ref) } \\
\text { Yes }\end{array}$ & $\begin{array}{c}1 \\
1 \cdot 76[0 \cdot 41-7 \cdot 61]\end{array}$ & $0 \cdot 449$ & $\begin{array}{c}1 \\
1 \cdot 30[0 \cdot 31-5 \cdot 40]\end{array}$ & $0 \cdot 717$ \\
\hline $\begin{array}{l}\text { Stimulant drug } \\
\text { use at } \\
\text { baseline }^{\S \S}\end{array}$ & $\begin{array}{l}\text { No (ref) } \\
\text { Yes }\end{array}$ & $\begin{array}{c}1 \\
0 \cdot 36[0 \cdot 05-2 \cdot 64]\end{array}$ & $0 \cdot 315$ & $\begin{array}{c}1 \\
0 \cdot 90[0 \cdot 27-2 \cdot 93]\end{array}$ & $0 \cdot 856$ \\
\hline $\begin{array}{l}\text { Body mass } \\
\text { index status }^{\S}\end{array}$ & $\begin{array}{l}\text { Severely thin (BMI<16) } \\
\text { Underweight (BMI: 16- } \\
\text { 18·49) } \\
\text { Normal weight (BMI: 18·5- } \\
24 \cdot 99 \text { ) (ref) } \\
\text { Overweight (BMI: 25-29·99) } \\
\text { Obese (BMI } \geq 30)\end{array}$ & $\begin{array}{c}5 \cdot 10[1 \cdot 25-20 \cdot 8] \\
0 \cdot 54[0 \cdot 13-2 \cdot 33] \\
1 \\
0 \cdot 70[0 \cdot 24-2 \cdot 04] \\
3 \cdot 50[1 \cdot 20-10 \cdot 2]\end{array}$ & $\begin{array}{l}0.520 \\
0 \cdot 021\end{array}$ & $\begin{array}{c}1 \\
1 \cdot 23[0 \cdot 58-2 \cdot 61] \\
1 \cdot 20[0 \cdot 29-4 \cdot 92]\end{array}$ & $\begin{array}{l}0 \cdot 582 \\
0 \cdot 801\end{array}$ \\
\hline
\end{tabular}

$\mathrm{CI}=$ confidence interval; $\mathrm{SHR}=$ sub-hazard ratio.

$\S$ Time-varying variable, descriptive statistics are given for the last available visit of each patient.

${ }_{\S}^{\S}$ Fixed variable, measured at baseline (i.e. at the first available visit of each patient).

* With robust standard errors

a Patients who reported living in hotels, accommodation centers, on the street or in therapeutic apartments were considered to have unstable housing.

${ }^{b}$ The presence of indirect clinical signs of cirrhosis was defined by one of the following: ascites, esophageal varices with or without bleeding, hepatic encephalopathy.

${ }^{c}$ Patients with a CES-D score $\geq 17(23)$ for men(women) were considered to have depressive symptoms. 
${ }^{\mathrm{d}}$ The following categories were used for average daily alcohol consumption: no consumption, low ( $\leq 1$ alcohol unit (AU)/day), moderate (1-3 AU/day for women and 1-4 AU/day for men), and elevated ( $>3 \mathrm{AU} /$ day for women and $>4 \mathrm{AU} /$ day for men).

${ }^{\mathrm{e}}$ Regular binge drinking was defined as drinking at least $5 \mathrm{AU}$ on one occasion at least once a week.

${ }^{\mathrm{f}}$ We used the following categories for average daily coffee intake: low ( $\leq 1 \mathrm{cups} /$ day), moderate (2 cups/day), and elevated ( $\geq 3$ cups/day). 
Table IV. Factors associated with HCV-related and non-HCV-related mortality (competing-risk regression models, multivariable analysis, the ANRS CO13 HEPAVIH cohort)

\begin{tabular}{|c|c|c|c|c|c|}
\hline & & $\begin{array}{r}\text { HCV-related me } \\
\text { (n=910 patients, } \\
\text { visits) }\end{array}$ & $\begin{array}{l}\text { tality } \\
=4,036\end{array}$ & $\begin{array}{r}\text { Non-HCV-rel } \\
\text { mortality } \\
\text { (n=974 patients, } \\
\text { visits) }\end{array}$ & $\begin{array}{l}\text { ted } \\
=4,341\end{array}$ \\
\hline & & aSHR [95\% CI] & $\begin{array}{c}\text { p- } \\
\text { value }\end{array}$ & aSHR $[95 \% \mathrm{CI}]$ & $\begin{array}{c}\mathrm{p}- \\
\text { value }\end{array}$ \\
\hline Gender & $\begin{array}{l}\text { Male (ref) } \\
\text { Female }\end{array}$ & $\begin{array}{c}1 \\
0 \cdot 31[0 \cdot 06-1 \cdot 45]\end{array}$ & $0 \cdot 136$ & $\begin{array}{c}1 \\
0 \cdot 99[0 \cdot 49-1 \cdot 98]\end{array}$ & 0.979 \\
\hline Age $(\text { years })^{\S}$ & & $0 \cdot 98[0 \cdot 92-1 \cdot 05]$ & 0.619 & $1 \cdot 01[0 \cdot 96-1 \cdot 06]$ & $0 \cdot 782$ \\
\hline $\begin{array}{l}\text { Having a steady } \\
\text { partner }^{\S}\end{array}$ & $\begin{array}{l}\text { No (ref) } \\
\text { Yes }\end{array}$ & & & $\begin{array}{c}1 \\
0 \cdot 48[0 \cdot 26-0 \cdot 90]\end{array}$ & 0.022 \\
\hline $\begin{array}{l}\text { Comfortable } \\
\text { housing }^{\S}\end{array}$ & $\begin{array}{l}\text { No (ref) } \\
\text { Yes }\end{array}$ & & & $\begin{array}{c}1 \\
0 \cdot 51[0 \cdot 26-0 \cdot 99]\end{array}$ & 0.047 \\
\hline $\begin{array}{l}\text { Post-treatment } \\
\text { HCV cure }\end{array}$ & $\begin{array}{l}\text { No (ref) } \\
\text { Yes }\end{array}$ & $\begin{array}{c}1 \\
0 \cdot 26[0 \cdot 03-1 \cdot 84]\end{array}$ & $0 \cdot 176$ & $\begin{array}{c}1 \\
0 \cdot 32[0 \cdot 10-1 \cdot 01]\end{array}$ & 0.052 \\
\hline $\begin{array}{l}\text { History of HCC } \\
\text { and/or liver } \\
\text { transplantation at } \\
\text { enrollment }^{\S \S}\end{array}$ & $\begin{array}{l}\text { No (ref) } \\
\text { Yes }\end{array}$ & $\begin{array}{c}1 \\
15 \cdot 1[4 \cdot 68-49 \cdot 0]\end{array}$ & $<10^{-3}$ & & \\
\hline $\begin{array}{l}\text { History of indirect } \\
\text { clinical signs of }\end{array}$ & $\begin{array}{l}\text { No (ref) } \\
\text { Yes }\end{array}$ & $\begin{array}{c}1 \\
3 \cdot 96[1 \cdot 28-12 \cdot 3]\end{array}$ & $0 \cdot 017$ & & \\
\hline
\end{tabular}




\begin{tabular}{|c|c|c|c|c|c|}
\hline $\begin{array}{l}\text { cirrhosis at } \\
\text { enrollment }^{\S \S a}\end{array}$ & & & & & \\
\hline $\begin{array}{l}\text { HIV CDC clinical } \\
\text { stage }^{\S}\end{array}$ & $\begin{array}{l}\mathrm{A} / \mathrm{B} \text { (ref) } \\
\mathrm{C}\end{array}$ & & & $\begin{array}{c}1 \\
2 \cdot 87[1 \cdot 53-5 \cdot 37]\end{array}$ & $0 \cdot 001$ \\
\hline $\begin{array}{l}\text { CD4 count } \\
\left(\text { cells } / \mathbf{m m}^{3}\right)^{\S}\end{array}$ & $\begin{array}{l}>500 \text { (ref) } \\
350-500 \\
200-350 \\
\leq 200\end{array}$ & $\begin{array}{c}1 \\
2 \cdot 21[0 \cdot 73-6 \cdot 70] \\
3 \cdot 30[1 \cdot 23-8 \cdot 84] \\
5 \cdot 24[1 \cdot 99-13 \cdot 8]\end{array}$ & $\begin{array}{l}0 \cdot 162 \\
0 \cdot 017 \\
0 \cdot 001\end{array}$ & & \\
\hline $\begin{array}{l}\text { Smoking status at } \\
\text { baseline }^{\S \S}\end{array}$ & $\begin{array}{l}\text { Current (ref) } \\
\text { Never/past }\end{array}$ & $\begin{array}{c}1 \\
0 \cdot 28[0 \cdot 10-0 \cdot 79]\end{array}$ & $0 \cdot 016$ & & \\
\hline $\begin{array}{l}\text { Regular binge } \\
\text { drinking at } \\
\text { baseline }^{\S \S b}\end{array}$ & $\begin{array}{l}\text { No (ref) } \\
\text { Yes }\end{array}$ & & & $\begin{array}{c}1 \\
2 \cdot 19[1 \cdot 10-4 \cdot 37]\end{array}$ & $0 \cdot 026$ \\
\hline $\begin{array}{l}\text { Coffee intake at } \\
\text { baseline }^{\S \S c}\end{array}$ & $\begin{array}{l}\text { Low/moderate (ref) } \\
\text { Elevated }\end{array}$ & $\begin{array}{c}1 \\
0 \cdot 38[0 \cdot 15-0 \cdot 95]\end{array}$ & $0 \cdot 040$ & & \\
\hline $\begin{array}{l}\text { Cannabis use at } \\
\text { baseline }^{\S \S}\end{array}$ & $\begin{array}{l}\text { Never/sometimes (ref) } \\
\text { Regularly/daily }\end{array}$ & $\begin{array}{c}1 \\
0 \cdot 28[0 \cdot 10-0 \cdot 83]\end{array}$ & $0 \cdot 021$ & & \\
\hline Body mass index ${ }^{\S}$ & $\begin{array}{l}\text { Severely thin (BMI<16) } \\
\text { Underweight (BMI: 16- } \\
18 \cdot 49) \\
\text { Normal weight (BMI: } \\
\text { 18·5-24-99) (ref) } \\
\text { Overweight (BMI: } 25- \\
29 \cdot 99) \\
\text { Obese (BMI } \geq 30)\end{array}$ & $\begin{array}{c}7 \cdot 25[2 \cdot 22-23 \cdot 6] \\
0 \cdot 49[0 \cdot 06-3 \cdot 86] \\
1 \\
0 \cdot 67[0 \cdot 23-1 \cdot 96] \\
2 \cdot 44[1 \cdot 00-5 \cdot 93]\end{array}$ & $\begin{array}{l}0 \cdot 001 \\
0 \cdot 497 \\
\\
0 \cdot 464 \\
0 \cdot 049\end{array}$ & & \\
\hline
\end{tabular}


aSHR=adjusted sub-hazard ratio; $\mathrm{CI}=$ confidence interval; $\mathrm{SHR}=$ sub-hazard ratio.

$\S$ Time-varying variable.

${ }_{\S}^{\S}$ Fixed variable, measured at baseline (i.e. at the first available visit of each patient).

* With robust standard errors

${ }^{\text {a }}$ The presence of indirect clinical signs of cirrhosis was defined by one of the following: ascites, esophageal varices with or without bleeding, hepatic encephalopathy.

${ }^{\mathrm{b}}$ Regular binge drinking was defined as drinking at least $5 \mathrm{AU}$ on one occasion at least once a week.

${ }^{\mathrm{c}}$ We used the following categories for average daily coffee intake: low ( $\leq 1 \mathrm{cups} /$ day), moderate (2 cups/day), and elevated ( $\geq 3$ cups/day). 